\title{
Examining Factors that Influence on Elementary Teachers' Perceptions in a Graduate Level Interdisciplinary Environmental Education Program: Using ePCK as a Framework
}

\author{
Young Joo Lee ${ }^{1}$, Hye-Eun Chu ${ }^{2}$, Sonya N. Martin ${ }^{1 *}$ \\ ${ }^{1}$ Seoul National University, Seoul, REPUBLIC OF KOREA \\ ${ }^{2}$ Macquarie University, Sydney, AUSTRALIA
}

Received 1 October 2017 • Revised 26 May 2018 • Accepted 29 May 2018

\begin{abstract}
This study describes the development and implementation of the Elementary School Teachers' ePCK (EST:ePCK) questionnaire to measure teachers' awareness about generalized PCK in the context of environmental education (EE). We compared responses of teachers who completed a graduate degree program designed to improve teachers' pedagogical content knowledge (PCK) for EE with those who did not attend the program. This allowed us to consider the potential impact of such a program on teachers' ePCK. Additionally, we examined what factors could contribute to differences in teachers' awareness about ePCK beyond their participation in a professional development program. Findings show that teacher education programs can have a positive influence on teachers' awareness about their own ePCK. However, in order to transform teachers' classroom practices, programs need to offer more instruction about how to actually implement EE topics using integrative approaches and in real classroom contexts. Findings also suggest the need for additional research focused on understanding the kinds of PCK teachers need to be able to integrate instruction across several content areas and makes clear the need for programs to make explicit to teachers when program goals seek to develop different kinds of PCK.
\end{abstract}

Keywords: elementary teacher, professional development for teaching environment, environmental Pedagogical Content Knowledge (ePCK), quantitative analysis, teacher education program

\section{INTRODUCTION}

Environmental education (EE) is becoming an increasingly important subject for preparing students to be aware of and responsive to changes in the earth's climate and environment. In Korea, EE was first established as an educational activity to be implemented throughout the whole curriculum in 1981. However, with the introduction of the revised National Curriculum in 1992, EE became a stand-alone mandatory subject, such as chemistry or biology, at the secondary level. Unfortunately, EE is not part of the required curriculum for elementary students, and elementary teachers in Korea have limited course work, experience, and formal training to prepare them to be able to effectively teach EE content. While EE is not part of the formal elementary curriculum, some environmental education issues, including conservation of natural resources, habitats, and ecosystems and pollution are each officially required to be taught as part of the elementary curriculum (Chu \& Treagust, 2009).

As there is no separate curriculum designed for instructing EE content at the primary school level in Korea, teachers must find ways to address these content objectives within the context of their regularly mandated subjects. Most teachers address these curriculum requirements using an integrated instructional approach referred to in Korea as "permeative instruction." This method relies on a multidisciplinary approach to integrating topics mandated by the national curriculum into lessons that are being taught as part of other related subjects, such as social studies, science, or ethics (Ahn, Choi, \& Cho, 2013; Nam, 1995). Such lessons are typically implemented as

(c) 2018 by the authors; licensee Modestum Ltd., UK. This article is an open access article distributed under the terms and conditions of the Creative Commons Attribution License (http://creativecommons.org/licenses/by/4.0/).

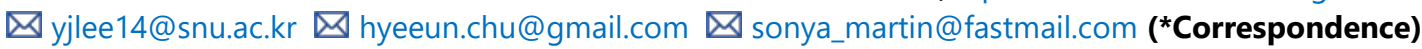




\section{Contribution of this paper to the literature}

- We discuss the development and validation of an instrument designed to measure Korean teachers' environmental pedagogical content knowledge (ePCK) and evaluate the impact of a teacher professional development program on participants' ePCK.

- We highlight factors that influence teachers' ePCK and discuss how different factors afford or limit teachers' efficacy in teaching environmental education at the primary grades.

- Our research has implications in terms of the need for teacher professional development programs to focus more attention on developing knowledge about content and how to implement content in real settings in order to promote growth and development in teachers' ePCK.

part of school discretion activities (SDA), which refers to additional instructional time set aside each month during which teachers can implement special lessons or take students on field trips. Lessons taught as part of SDA tend to be one-off attempts at covering isolated content requirements with a single lesson. For example, teachers may teach students how to properly wash their hands to prevent the spread of germs and infections to fulfill health-related learning objectives included in the curriculum related to health and hygiene. Alternatively, teachers can also take advantage of time allotted for creative discretion activities (CDA), which is an instructional time period that teachers can use to implement educational programs with a multi-faceted series of connected lessons. CDAs were introduced at the elementary level to encourage teachers to develop more hands-on learning activities for students.

Currently, these two options (SDA and CDA) offer teachers up to 68 additional teaching hours per year - during which they can implement specialized curriculum for students in Grades 1-6. As a result, there is increased potential for teachers to address EE topics at the elementary level. However, a survey of primary school teachers revealed that only $34 \%$ of elementary schools implement any EE lessons or programming (Korean Ministry of Environment [KMOE], 2010). There could be several reasons why teachers may choose to implement content other than EE during SDA/CDA times, including the lack of curriculum resources such as textbooks, worksheets, and guides to support teachers' instruction. For example, curriculum programs that include commercially developed educational materials, such as those focused on teaching English as foreign language (EFL), may be easier for teachers to implement (Kwon \& Yun, 2010). Currently, there are many programs offering teachers ready-made lessons and material resources for teaching topics in arts-integrated STEM (STEAM) curriculum, robotics, and computing. Korean elementary teachers have many choices to fill this flexible instructional time and they have autonomy to decide which content they will introduce to students. As such, these teachers are key stakeholders in determining what primary students will learn about environmental education. To date, however, there have been no studies examining Korean teachers' capacity for developing, implementing, and assessing students' learning from integrated EE lessons in their classrooms.

To help address the complexity of supporting teachers' capacity to integrate content across the curriculum, the Korea Institute for Curriculum and Evaluation (KICE, 2007) suggested that teacher preparation programs should be designed to support the growth and development of teachers' ability to meet this goal. Specifically, KICE recommended that professional development programs should aim to expand not only teachers' content knowledge but also their pedagogical content knowledge. This recommendation is one policy-driven attempt help improve teachers' capacity for developing and teaching integrated content. In response, several universities have developed new interdisciplinary environmental education master degree programs that have been designed to target teaching professionals who sought to improve their EE content understanding and their knowledge about how to teach environmental education in schools. Graduation requirements include both science and educationbased coursework and a research-based thesis focused on various topics in EE and education. With the proliferation of such programs in the last decade, researchers anticipate that they will find that more teachers may have improved knowledge about EE subject matter and pedagogical knowledge about how to teach EE in schools. There has been research conducted to access how pedagogical content knowledge frameworks have been used to guide the development of teacher education and professional development programs for Korean teachers (Park, 2014), but there have been no studies examining elementary teachers' awareness of their pedagogical content knowledge related to environmental education.

This study seeks to fill this gap by describing the development and implementation of a questionnaire, Elementary School Teachers' ePCK 1 (EST:ePCK), designed to measure elementary teachers' awareness about different components of pedagogical content knowledge associated with environmental education. In addition, we employed the EST:ePCK questionnaire to evaluate the effectiveness of a professional development program

${ }^{1}$ Previous research focusing on environmental knowledge related to teaching has introduced abbreviations such as PCK-EE, ePCK, and EPCK. In this study, we borrow from previous work by Cho (2010) to emphasize the study of teachers' PCK within EE by using the acronym ePCK. For more details, please consult the theory section. 
designed to improve Korean teachers' knowledge and capacity for integrating EE into the elementary curriculum. We did so using an experimental research design comparing responses of elementary teachers who participated in a graduate level interdisciplinary EE (GIEE) program designed to improve understanding of content, research, and pedagogy related to EE topics with responses from elementary teachers who did not participate in the program. Comparing participant responses allowed us to consider the potential impact of the GIEE program on teachers' ePCK and allowed us to examine other factors that could contribute to differences in teachers' awareness about ePCK beyond participation in a professional development program. The following questions informed our inquiry:

1. How does elementary teachers' awareness of their own ePCK differ between those who participated in the GIEE program and those who did not?

2. What impact do different factors (such as number of years teaching, previous professional development experience, age, or gender) have on elementary teachers' awareness of ePCK?

3. Which GIEE program experiences had the greatest influence on elementary teachers' awareness about ePCK and why?

Findings from our study offer implications for how the GIEE program, and others like it, could be more effectively designed and refined to enhance the professionalization of EE teaching that is needed at the elementary level. In addition, the results from this study offer implications for PCK- and EE-related research and teacher professional development in contexts outside of Korea that have similar expectations for teachers' use of integrative instruction of EE in the primary grades. Our findings also suggest the need for additional research focused on understanding the kinds of PCK teachers need to be able to integrate instruction across several content areas and encourage us to raise questions about the need to make explicit to teachers when programs have goals of developing different kinds of PCK.

In the sections that follow, we provide a brief overview about PCK as a theoretical framework for supporting this research. We focus attention on research related to PCK in the context of EE and elementary education with a goal of making clear which PCK constructs informed our development of the EST:ePCK questionnaire. Specifically, we offer additional justification about the importance of knowledge domains that we believe are salient for supporting the integrative instructional approach necessary for Korean teachers to successfully teach EE in the primary grades.

\section{THEORETICAL FRAMEWORK}

\section{Pedagogical Content Knowledge (PCK)}

In this study, we approach our inquiry from the perspective of understanding teachers' pedagogical content knowledge (PCK) concerning environmental education. Since Shulman (1986) first introduced PCK as a theoretical construct to describe various forms of knowledge teachers use (including most notably, knowledge of subject matter and pedagogy) to represent and to make content comprehensible to students, there have been numerous studies in science teacher education to explore PCK in science (for a review, see Abell, 2008). Magnusson, Krajcik, and Borko (1999) explained PCK as the combination of one's knowledge about subject matter, pedagogy, and context of the learner and setting, all of which inform one's ability to effectively teach. When viewed from this perspective, PCK can be seen as both a single domain of teachers' knowledge and an overarching domain that can be utilized to integrate and transforms other knowledge domains. Researchers have found PCK useful for categorizing and exploring different aspects of teachers' professional knowledge and for considering how this knowledge is utilized during instruction (Loughran, Mulhall, \& Berry, 2008). While numerous studies in science education have applied PCK as a framework for considering the kinds of teachers' knowledge that exist, few have asked teachers to explicitly reflect on their own PCK relative to teaching science (Kind, 2009). Instead, PCK research often focuses on identifying the kinds of PCK needed to effectively teach content to different groups of learners. Building from these findings, researchers generally work to create educational programs that will most benefit the development of different aspects of pre- and in-service teachers' knowledge about how to most effectively teach science content (Loughran, Berry, \& Mulhall, 2004).

\section{Environmental Education (EE) and Pedagogical Content Knowledge (PCK)}

PCK has been examined and explored by several researchers in the field of EE, but only at the secondary level. Most recently, Zhou (2015) introduced the environmental pedagogical content knowledge (EPACK) framework describing the knowledge teachers need in order to reduce the gap between curriculum policy and classroom practice in EE. The EPACK framework consists of three knowledge domains (content, pedagogy, and environment) that interact with and generate different forms of blended knowledge. Although Zhou's work offered implications about the necessity for PCK approaches to be used in developing teachers' professional development programs, he 
Table 1. Subscales for PCK in previous research studies

\begin{tabular}{|c|c|c|c|c|c|c|c|}
\hline \multirow{2}{*}{ Questionnaire \& Framework } & \multicolumn{7}{|c|}{ Subscales } \\
\hline & KSM & KC & KL & KIS & KEC & KEG & KE \\
\hline $\begin{array}{l}\text { PCK in STEST: Science Teaching for Elementary School Teachers (Park, } \\
\text { 2003a; 2003b) }\end{array}$ & $\checkmark$ & $\checkmark$ & $\checkmark$ & $\checkmark$ & $\checkmark$ & $\checkmark$ & $\checkmark$ \\
\hline ePCK for ET: ePCK framework for Environment Teachers $(C h o, 2010)$ & $\checkmark$ & $\checkmark$ & $\checkmark$ & $\checkmark$ & $\checkmark$ & $\checkmark$ & $\checkmark$ \\
\hline $\begin{array}{l}\text { TPCK in EE: Teachers' PCK in Environment Education (Abdullaha \& } \\
\text { Halima, 2010; 2012) }\end{array}$ & $\checkmark$ & $\checkmark$ & $\checkmark$ & $\checkmark$ & & & $\checkmark$ \\
\hline PCxK model: Pedagogical Context Knowledge model (Birdsall, 2015) & $\checkmark$ & $\checkmark$ & $\checkmark$ & $\checkmark$ & $\checkmark$ & & \\
\hline
\end{tabular}

did not identify PCK components reflecting specific features associated with EE. Other researchers have explored concepts and components of PCK in EE, both quantitatively and qualitatively (Abdullah \& Halim, 2010, 2012; Cho \& Choi, 2009; Cho, 2010); however, they mainly studied PCK of EE based on previous PCK studies in science education (see Table 1).

While Abdullah and Halim (2012) asserted the need for researchers to explore how teachers integrate knowledge about EE and pedagogical knowledge, limited work has been done in this area-especially at the elementary level. Two studies by Shumba and Kampamba $(2012,2013)$ considered what kinds of PCK elementary teachers would need to effectively teach education for sustainable development (ESD) topics at the primary level. These researchers contributed to the development of ESD PCK by relating pre-service science teachers' understandings of ESD concepts, principles, and values with categories of ESD content knowledge and pedagogical knowledge identified as being necessary for adequately teaching ESD concepts to students. Findings from their study indicated that current teacher education programs for ESD did not prepare teachers to be able to effectively teach ESD issues.

Cho's (2010) framework for environmental pedagogical content knowledge (ePCK) was originally developed to measure PCK for secondary school EE teachers. Cho's framework differed somewhat from both Park (2003a, 2003b) and other studies (see Abdullaha \& Halima, 2010, 2012; Birdsall, 2015) related to PCK of EE in that Cho included environmental education-specific knowledge domains. In addition, Cho was also careful to situate each domain in the context of environmental education. We adopted the same perspective when developing our instrument. Park's (2003a, 2003b) examination of elementary teachers' PCK for general science teaching was also informative in the development of our questionnaire. Both Cho and Park's framing of PCK were compatible with our own perspectives concerning which knowledge domains are most salient for being an effective teacher of EE topics and of elementary school children.

In developing our own tool, we referenced several previously validated instruments (see Cho \& Choi, 2009; Cho, 2010) and adapted selected items by editing them to reflect specific features of PCK for teaching EE at the elementary level. For example, an item from Cho's questionnaire for secondary teachers, which read, "I am aware of the environmental education curriculum standards and the materials needed to teach this content" was adopted for our use as, "I can interpret and evaluate contents of environmental education curriculum and align it with other appropriate curriculum subjects." By adopting components from curriculum documents drawn from Marcinkowski, Volk, Hungerford, and Kronholm (1990), standards suggested by the Korea Society for Environmental Education [KOSEE] (2014), and principles for the evaluation of EE (Nam, Choi, Kim, \& Ha, 2001), we were able to integrated environment-based content.

\section{Environmental Pedagogical Content Knowledge (ePCK) for Elementary Teachers}

Drawing from all these resources, we developed the EST:ePCK questionnaire. The EST:ePCK questionnaire has 63 items and is divided into three main sections: a demographics section (Items 1-12), an ePCK section with seven sub-scales (Items 13-51), and a section designed to evaluate teachers' learning experiences relevant to ePCK domain knowledge while participating as students in the GIEE program (Items 52-63).

Table 2 displays the composition of the questionnaire, which includes the scales, sub-scales of ePCK, and number and format of items in each section. Similar to Cho's (2010) and Park's (2003a, 2003b) tools, we included seven PCK domains in our questionnaire, including knowledge of subject matter (KSM), knowledge of curriculum $(\mathrm{KC})$, knowledge of learner (KL), knowledge of instructional strategies (KIS), knowledge of environmental context (KEC), knowledge of educational goals (KEG), and knowledge of evaluation (KE). 
Table 2. Composition of EST:ePCK survey questionnaire

\begin{tabular}{|c|c|c|c|}
\hline $\begin{array}{l}\text { Section } \\
\text { (Number of items) }\end{array}$ & Contents and subscales & Item number & Format \\
\hline $\begin{array}{l}\text { Demographic } \\
\text { questions } \\
\text { (12 items) }\end{array}$ & $\begin{array}{l}\text { Gender, age, career, education level, information about } \\
\text { working experience, and about whether teachers engaged } \\
\text { in EE training programs }\end{array}$ & $1-12$ & $\begin{array}{l}\text { Closed-ended and } \\
\text { multiple choice } \\
\text { format }\end{array}$ \\
\hline \multirow{7}{*}{$\begin{array}{l}\text { Subscales of } \\
\text { ePCK } \\
\text { (39 items) }\end{array}$} & Knowledge of Subject Matter & $13-17$ & \multirow{7}{*}{$\begin{array}{l}4 \text { point Likert scales } \\
\text { and } \\
\text { Open-ended } \\
\text { question format }\end{array}$} \\
\hline & Knowledge of Curriculum & $18-21$ & \\
\hline & Knowledge of Learner & $22-26$ & \\
\hline & Knowledge of Instructional Strategies & $27-31$ & \\
\hline & Knowledge of Environmental Context & $32-37$ & \\
\hline & Knowledge of Educational Goal & $38-45$ & \\
\hline & Knowledge of Evaluation & $46-51$ & \\
\hline $\begin{array}{l}\text { Teachers' experience } \\
\text { GIEE } \\
\text { (12 items) }\end{array}$ & $\begin{array}{l}\text { Admission and graduation year, motivation, general } \\
\text { satisfaction of the course, self-evaluation about influence } \\
\text { on ePCK, general comments on the program }\end{array}$ & $52-63$ & $\begin{array}{l}\text { Closed and open- } \\
\text { ended question } \\
\text { format }\end{array}$ \\
\hline
\end{tabular}

\section{SALIENT KNOWLEDGE DOMAINS FOR MEASURING TEACHERS' AWARENESS OF ePCK}

In this section, we provide a brief description for each of the seven domains we believe to be salient for supporting integrative EE teaching approaches at the elementary level. The inclusion of knowledge of subject matter (KSM), knowledge of the curriculum (KC), knowledge of educational goals (KEG), and knowledge of environmental context (KEC) domains are critical for considering how teachers integrate EE content into and across other content areas. While teacher preparation programs for elementary teachers in Korea have limited coursework for instructing environmental education subject matter, teacher candidates take several general science courses for certification requirements. Specialized graduate degree programs in EE place an emphasis on developing teachers' knowledge of EE subject matter (KSM) in part because they recognize teachers' lack of development in this area.

We found Cho's (2010) EE PCK framework compelling because he asserted the need to separate the subscales of knowledge of the curriculum (KC) and knowledge of educational goals (KEG). We also agree this distinction is important for teaching EE topics in the primary grades because teachers are required to set learning goals by trying to align and integrate EE curriculum, which is not a compulsory subject, with mandatory curriculum subjects. This requires teachers to have an understanding not only of EE-related KC, but also knowledge of the fundamental goals and objectives related to EE as presented in such documents as the Belgrade Charter (UNESCO-UNEP, 1976), the Tbilisi Declaration (UNESCO, 1978), and Agenda 21 (UNCED, 1992). Knowledge of educational goals (KEG) for EE as described in these seminal documents is critical for considering what kinds of educational goals environmental education should promote in learners. Examples of educational goals described in these documents include supporting students to be able to think critically, ethically, and creatively when evaluating environmental issues and to develop skills and commitment to action that can sustain and enhance the environment (Ardoin, Bowers, Roth, \& Holthuis, 2018).

In addition to understanding overarching learning goals related to EE, teachers also need knowledge of the curriculum $(\mathrm{KC})$ learning goals at the primary grades. Examples of $\mathrm{KC}$ include being aware of curriculum themes, such as ecosystems, water and land resources, conservation and pollution, and impact of humans on the environment. Teachers need knowledge of content to be taught, such as understanding the relationships between animals, their habitats, and humans and identifying different energy sources and their uses and conservation strategies. As mentioned previously, teachers have few curriculum resources, such as textbooks or assessment tools, to support EE instruction and evaluation at the elementary level. In 2014, the Ministry of Education published a curriculum standard guide for environmental education topics that includes a suggested content (such as environmental problems) that can align with targeted topics taught in other subjects (such as science or social studies). To make use of this guide, teachers need to be familiar with EE-related content and understand interdisciplinary features of environmental education so they can make authentic connections with content in other subject areas (Engleson \& Yochers, 1994). This requires teachers to have knowledge of subject matter (KSM) and knowledge of curriculum (KC) for EE, but also all the other subjects taught at the elementary level. In addition, students' learning of this content needs to be informed by the greater educational goals and also needs to be contextualized to provide students with an awareness of their local environmental issues in relation to national and international issues. This will also require that teachers have knowledge of environmental context (KEC). A teachers' KEC can be informed by participation in professional development and academic activities designed to expand their knowledge of EE content in context (NAAEE, 2010). 
Finally, teachers need to understand the psychological characteristics of students to be able to target instruct students in ways that are appropriate and accessible (Choi, Choi, Kim, \& Kim, 2014). Teachers need sufficient knowledge of learners (KL) to be able to effectively consider students' interests and preconceptions about the environment and to anticipate students' capacity for engaging in inquiry about environmental phenomena. To be effective, teachers need adequate knowledge of instructional strategies (KIS) to be able to use various teaching methods and strategies appropriate for both EE content and context (NAAEE, 2010). Finally, teachers need knowledge of evaluation (KE) to be able to determine teaching effectiveness and to evaluate students' development and growth in knowledge and achievement.

\section{METHODS}

This is a quantitative research study employing statistical analysis of questionnaire responses to identify Korean teachers' awareness about their own PCK related to the teaching of environmental education topics at the elementary level. Specifically, we sought to examine Korean primary school teachers' perceptions on environmental pedagogical content knowledge (ePCK) and to identify factors that have an influence on Korean teachers' ePCK. A comparative analysis of survey responses by two groups of teacher participants (those who participated in the program and those who did not) was also conducted to demonstrate the effectiveness of using the EST:ePCK questionnaire to evaluate a professional development program designed to improve elementary teachers' instruction of environmental education topics. Using these findings, we discuss the impact of program participation on these teachers' awareness of ePCK. In the following sections, we provide context for data collection by describing the participants and the GIEE program and we detail the methodology used to collect and analyze the data.

\section{Research Context}

The GIEE is a two-year multidisciplinary master's degree program for environmental education designed for teaching professionals and offered at prominent university located in Seoul. We situated this research in this context because the GIEE serves a large population of elementary teachers and because the GIEE is representative of a growing trend of specialized program development by graduate schools offering training programs for in-service teachers (Koh et al., 2007). Such programs, which are generally located in research-based teacher education institutions, provide students with project-based coursework involving faculty in science and education departments. We reasoned that understanding how different features of the GIEE program have an impact on elementary teachers' PCK related to EE could have important implications for designing programs that can have a positive impact on how EE is taught and learned in Korean elementary schools. We also imagined our findings could reveal aspects of the program that could be strengthened. As such, we intended to provide critical feedback aimed at effecting positive changes in the GIEE in hopes of improving elementary teachers' ability to more effectively implement EE in their own classrooms.

\section{The GIEE Program}

Courses in the GIEE program are designed to support the development of professional teachers as they acquire additional theoretical knowledge that can enhance their classroom teaching practices (Kwak, 2011). The GIEE program was developed as a collaborative effort between 13 professors from six different departments including science education, social sciences, and various environmental sciences-related departments. The GIEE program seeks to provide professional environmental educators with "specialized research opportunities designed to allow participants to develop their own personalized learning" (GIEE program website, 2016). To graduate from the GIEE program, participants must complete 24 course credits and write a thesis related to environmental issues to be examined from the perspective of the natural sciences, social sciences, or humanity studies.

The curriculum structure of the GIEE program consists of tracks of courses, the Pedagogical Content Knowledge of EE track and the Subject Matter Knowledge of Environmental Studies track (see course overview in Table 3). Teachers need to select nine credits from 20 elective subjects distributed across these two tracks. In addition, teachers take nine required credits, including coursework focused on special topics in EE and dissertation research. The goal of the program is for teachers to graduate with a master's degree with a diverse range of knowledge and experiences and to support teachers to conduct research with faculty members in the program. If teachers want to take additional credits, they can choose from various courses in other majors to support unique interests. For example, teachers may take courses in botany or chemistry or they may choose courses related to social sciences. The course selection for teachers depends upon their master's thesis topic. The thesis provides teachers an opportunity to integrate knowledge about environmental content and pedagogical content through research. 
Table 3. Curriculum of GIEE program

\begin{tabular}{ccc}
\hline Tracks & & Examples of courses in each track \\
\hline Mandatory & Related to pedagogical knowledge & Special Topics in EE \\
\cline { 2 - 3 } $\begin{array}{c}\text { Subjects } \\
\text { (9 credits) }\end{array}$ & Related to environmental contents & Dissertation Research \\
\hline \multirow{2}{*}{$\begin{array}{c}\text { Elective subjects } \\
(9 \text { credits })\end{array}$} & \begin{tabular}{l} 
Related with pedagogical knowledge \\
\cline { 2 - 3 }
\end{tabular} & $\begin{array}{c}\text { Study of Science Education, Sociocultural Approached to Science } \\
\text { Education Research, Studies in Our Living Environment, Study of } \\
\text { Ecology Education, etc. }\end{array}$ \\
\cline { 2 - 3 } & Related with environmental contents & $\begin{array}{c}\text { Environmental Economics, Urban Geography, Ecology, Climate } \\
\text { Research, etc }\end{array}$ \\
\hline
\end{tabular}

Table 4. Item Content Validity Index (I-CVI) of each item $(\mathrm{N}=10)$

\begin{tabular}{|c|c|c|c|c|c|c|c|}
\hline \multirow{2}{*}{ Subscale } & \multicolumn{7}{|c|}{ CVI of each item } \\
\hline & 1 & 2 & 3 & 4 & 5 & 6 & 7 \\
\hline Knowledge of Subject Matter & 0.9 & 0.9 & 0.7 & 0.9 & 0.9 & 1.0 & \\
\hline Knowledge of Curriculum & 0.9 & 1.0 & 0.9 & & & & \\
\hline Knowledge of Learner & 0.9 & 1.0 & 0.9 & 0.9 & & & \\
\hline Knowledge of Instructional Strategies & 0.9 & 1.0 & 1.0 & 1.0 & 1.0 & 1.0 & \\
\hline Knowledge of Environmental Context & 0.9 & 0.9 & 0.9 & 0.9 & 0.9 & 0.9 & \\
\hline Knowledge of Educational Goal & 1.0 & 1.0 & 1.0 & 1.0 & 0.9 & 0.9 & \\
\hline Knowledge of Evaluation & 1.0 & 0.9 & 0.8 & 0.9 & 1.0 & 1.0 & 1.0 \\
\hline
\end{tabular}

GIEE faculty members are appointed from various departments throughout the university, and they offer 16 different courses specially designed to enhance teachers' understandings about environmental education. A goal for faculty is to provide teachers a balance of options that can improve teachers' content knowledge and pedagogical knowledge. PCK as a theoretical construct is a central component for program and course design and teacher participants are made explicitly aware of the program's goal for expanding teachers PCK related to environmental education. For these reasons, we selected this program for participant recruitment to implement our instrument.

\section{INSTRUMENT VALIDATION PROCESS}

These survey items were further developed to measure ePCK for primary school teachers by conceptualizing specific domains of ePCK that primary school teachers need in order to be able to incorporate EE knowledge into the design and implementation of effective lessons in elementary classroom contexts. Instead of conducting a pilot test, all items were discussed in focus-group discussions conducted with three primary school teachers. Based on teachers' evaluation and feedback, item terms and sentences were revised. Additionally, following the focus group discussion, researchers carefully discussed each item and made additional revisions to the overall design of the questionnaire. We gathered additional feedback about revised survey items and scales by presenting our instrument design and developmental framework to colleagues at a conference of Korean Society of Environmental Education (KOSEE).

Additionally, we invited 10 experts from the fields of environmental sciences, environmental education, and elementary science teacher education to evaluate the items on the EST:ePCK. Using a 4-point Likert scale, these 10 experts rated each of the 39 items on clarity $(1=$ ambiguous to $5=$ clear $)$ and on domain appropriateness $(1=$ not relevant description of domain and 5 = very relevant description) to help us obtain content and face validity (see Table 4). We computed content validity using the item content validity index (I-CVI) method (Lynn, 1986). Using this method, items that scored less than 0.90 on both clarity and domain appropriateness were revised (see Table 4 for I-CVI values).

Except for one item statement in the knowledge of subject matter (KSM) domain, most of the items were found to be at an adequate level (no lower than 0.78). Several EE experts provided advice to include items in the knowledge of curriculum (KC), knowledge of learner (KL), and knowledge of educational goal (KEG) sections. For example, to assess teachers' knowledge about specific resources useful for designing curriculum, we added Item 20, "I understand that in order to successfully implement environmental educational lessons or programs, I need to assess EE curricula goals at the national, local, and school levels." In addition, it was suggested that we delete Item 15, "I know the effects of human activities on the environment," from the KSM sub-scale due to its low content validity score $(\mathrm{CVI}=0.70)$. We also decided to revise Item 14 from the KSM section even though the content validity score was quite high $(\mathrm{CVI}=0.90)$. Experts worried the content description was too vague, so we changed the wording from "I know the main environmental-ecological concepts and principles" to "I know the main concepts 
Table 5. Rasch measurement model information

\begin{tabular}{ccccc}
\hline \multicolumn{2}{c}{ Subscale name } & Mean (MNSQ) & \multicolumn{2}{c}{ Reliabilities } \\
\hline $\mathrm{KSM}$ & Infit & Outfit & Item & Person \\
\hline $\mathrm{KC}$ & 0.96 & 0.93 & 0.96 & 0.73 \\
\hline $\mathrm{KL}$ & 0.98 & 0.96 & 0.98 & 0.64 \\
\hline $\mathrm{KEC}$ & 0.98 & 0.91 & 0.91 & 0.74 \\
\hline $\mathrm{KIS}^{*}$ & 0.98 & 0.70 & 0.94 & 0.75 \\
\hline $\mathrm{KEG}^{*}$ & 0.98 & 0.76 & 0.74 & 0.79 \\
\hline $\mathrm{KE}^{*}$ & 0.95 & 1.02 & 0.62 & 0.84 \\
\hline $\mathrm{KIS}^{*}, \mathrm{KEC}^{*}, \mathrm{KEG}^{*}, \mathrm{KE}^{*}$ : items in these scales show appropriate infit only & 0.97 & 0.64 & 0.72 \\
\end{tabular}

Table 6. Reliabilities of the instrument

\begin{tabular}{llc}
\hline Subscale & Subscale summary & $\begin{array}{c}\text { Cronbach alpha } \\
\text { Reliability }\end{array}$ \\
\hline $\begin{array}{l}\text { Knowledge of Subject Matter } \\
\text { (5 items) }\end{array}$ & $\begin{array}{l}\text { Teachers' knowledge about environmental education content needed to } \\
\text { help guide students' to learn major concepts in environmental education }\end{array}$ & 0.80 \\
\hline $\begin{array}{l}\text { Knowledge of Curriculum } \\
\text { (4 items) }\end{array}$ & $\begin{array}{l}\text { Knowledge necessary for teachers to be able to understand and manage } \\
\text { the curriculum related to environmental education }\end{array}$ & 0.75 \\
\hline $\begin{array}{l}\text { Knowledge of Learner } \\
\text { (5 items) }\end{array}$ & $\begin{array}{l}\text { Teachers' knowledge and understanding about the learners in their } \\
\text { environmental education class }\end{array}$ & 0.84 \\
\hline $\begin{array}{l}\text { Knowledge of Instructional } \\
\text { Strategies }\end{array}$ & $\begin{array}{l}\text { Teachers' knowledge about the kinds of teaching/learning methods that } \\
\text { are suitable for lessons in environmental education }\end{array}$ & 0.92 \\
\hline $\begin{array}{l}\text { Knowledge of Environmental } \\
\text { Context } \\
\text { (6 items) }\end{array}$ & $\begin{array}{l}\text { Teachers' knowledge about what social, cultural, and material resources } \\
\text { can be used for teaching environmental education content }\end{array}$ & 0.92 \\
\hline $\begin{array}{l}\text { Knowledge of Educational Goal } \\
\text { (8 items) }\end{array}$ & $\begin{array}{l}\text { Knowledge required for teacher to be able to set a appropriate learning } \\
\text { goals for students in environmental education }\end{array}$ & 0.92 \\
\hline $\begin{array}{l}\text { Knowledge of Evaluation } \\
\text { (6 items) }\end{array}$ & $\begin{array}{l}\text { Knowledge necessary for applying assessment methods suitable for } \\
\text { measuring students' learning in environmental education }\end{array}$ & 0.83 \\
\hline
\end{tabular}

and principles that are necessary to understand the environment." Additional small edits were made to Items 19, 25, 39, and 40. Examples include clarifying language (\#19 and \#25) and dividing one item into two statements (\#39 and \#40). These edits allowed us to develop clearer items that more carefully reflected salient concepts to be taught in elementary environmental education courses, including interdisciplinary approaches to EE, inquiry-based EE, and promoting responsible environmental behaviors. At the end of this process, 39 items were developed.

We conducted construct validity The WINSTEPS software program to conduct Rasch measurement modeling to determine if the items we developed measure intended constructs. In Table 5, the infit and outfits present weighted and unweighted statistics used (Bond and Fox, 2007). Items are generally considered to have acceptable fit within the range of infit and outfit values, 0.7-1.3 and $z$ scores for infit and outfit, less than $2\left(\left|z_{\text {infit }}\right| \leq 2\right.$ and $\mid z$ outfit $\mid \leq 2)$. The subscales identified as representing key areas of focus for the research in environmental Pedagogical Content Knowledge (ePCK) all fit within an acceptable range. Rasch modeling also allows an estimation of both item difficulty and student ability for a test (see Table 5).

These reliabilities are based on reliability of distinction among items or a person, respectively. Although person reliabilities are much lower than item reliabilities, but they are moderate for all scales. The item reliability in KIS*, $\mathrm{KEC}^{*}, \mathrm{KEG}^{*}$ and $\mathrm{KE}^{*}$ scales are lower than other scales and the values indicate appropriate infit only between the measurement model and students' responses. Thus, it is clear that the reliabilities in each subscale can be improved in future studies by developing more varying levels of items for these three subscales. In addition, in future studies we can also improve reliability by including more participants. As more items and participants increase, reliabilities generally improve as these changes impact values (infit and outfit) that can be indicative of a good fit. In addition, the Cronbach reliabilities alpha for each subscale is provided in Table 6.

The subscales for each knowledge domain had high Cronbach alpha values, ranging from 0.75 to 0.92 . These values indicate that the items within each subscale show moderate to high internal consistency and accurately reflect the kind of knowledge being investigated for each knowledge domain. Nunally and Bernstein (1994) indicated that the set of items which deal with knowledge could show lower Cronbach alpha reliability than set of items in affective related areas, e.g. attitude or interests. We also conducted explanatory factor analysis. All the items were fit in one scale. Also, the item-total correlation was all above 0.50-0.90, with the exception of item 51, which means that all items have ability to discriminate elementary teachers' ePCK. Item 51 showed a correlated 
item-total correlation of 0.10 . Even though, we decided to keep the item to measure how teachers use assessment outcomes from EE oriented lessons to inform their teacher instruction. Following Samuel Messick' unified concept of validity (1995), we concluded from the item validation process described above that the items on this instrument are promising enough to use at this stage in the instrument development. However, we believe items should be further developed to evaluate student teachers' ePCK in the future.

\section{IMPLEMENTATION OF SURVEY}

After the validation process was complete, the items from the survey were input into an electronic survey system called Survey Monkey (https://ko.surveymonkey.com). With permission from both the Institutional Review Board (IRB) at the university that hosts the GIEE program and from the GIEE program administrators, we obtained a list of email addresses for all past GIEE participants and we sent an email invitation to ask the graduates of the program to complete our questionnaire. The email contained a URL link to the EST: ePCK questionnaire. We collected data over a two-week period near the end of 2015. The email explained that participation was voluntary, that all information submitted was non-identifiable, and that no personally identifiable information would be collected during the survey.

In addition to the GIEE participants, we randomly sampled non-GIEE elementary teachers by using the snowball method, whereby we sent an email invitation to ten elementary teachers who were not participants in the GIEE and whom we could contact via normal research and educational networks. These email invitations included a URL link to our online questionnaire. These participants were asked to take the survey and forward the email to five or more colleagues. We continued data collection in this manner over a two-week period, the end of which netted 122 participant responses. In the sections that follow, we describe each group of participants independently.

\section{Study Participants}

In total 173 teachers participated in the survey (GIEE group, N=51; non-GIEE group, N=122). However, out of the 173 submitted surveys, 43 were found to be incomplete and so could not be evaluated. Thus, a total of 130 teachers' responses (GIEE group, $\mathrm{N}=44$; non-GIEE group, $\mathrm{N}=86$ ) were valid and analyzed.

GIEE Participants: While the GIEE program is designed to support the development of EE, participants do not need to be teachers to enroll in the program. However, since the first class of students was admitted to the GIEE program in 1999, the majority of participants have been in-service teachers in primary and secondary schools. Since then, $50.9 \%$ of participants have been elementary teachers, compared to $14.8 \%$ who were secondary school teachers, and $34.3 \%$ who were non-teachers. The proportion of elementary teachers enrolling in the GIEE has gradually increased over the last decade. For example, in 2015, seven of eight (87.5\%) new teachers accepted to the program were elementary teachers. Information about teacher participants in the GIEE are based on data from internal evaluation reports of the GIEE program, which includes details about the number of applicants who have entered and/or graduated from the program. These reports also offer details about anonymous participants' career histories, courses of study, and individual teachers' goals for academic development in the program. At the time the data was collected for this study, a total of 55 elementary teacher participants had graduated from the GIEE program. Of the 55 possible respondents, a total of 51 teachers completed our survey for a response rate of $80 \%$.

Non-GIEE Participants: As the maximum number of teachers enrolled in the GIEE group was set at 55 possible participants, we calculated the necessary sample size for the non-GIEE group using G*Power 3.1. Using this actual power value, with effect size of 0.6 , can be used to predict a reasonable sample size of non-GIEE teachers needed for this study (Faul, Erdfelder, Lang, \& Buchner, 2007). Our G*Power analysis suggested the sample size for the non-GIEE group should be at least 85 teachers (with an actual power of 0.9 and effect size $=0.6, p<0.05$ ), thus our sample size is sufficient for analysis.

\section{DATA ANALYSIS}

We analyzed the data quantitatively using SPSS (version 20). First, descriptive statistics was completed to describe teachers' awareness of ePCK. Next, an independent sample $t$ test was conducted to compare awareness of ePCK between both teacher groups (see first two sections in Table 7). Then we conducted ANOVA to investigate the influences of demographics and teachers' experiences on all seven subscales in the ePCK section. Effect size was reported when $t$ test and ANOVA tests were conducted. Eta square values were taken from ANOVA analysis output as effect size to report the strength of variable (e.g. PD experiences, gender, etc.) influences. Also, effect size was calculated when the $t$ test was conducted. The calculation formula is as follows: Effect Size $=t 2 / t 2+(N 1+N 2-$ 2) (t: $t$ test value, N1: sample size in group1, N2: sample size in group2). Using Cohen's guidelines (1988, p. 284287) for interpreting these values, we report effect size to be small if $=0.01$, medium if $=0.06$, and large if $=0.14$. 
Table 7. Comparison of overall mean scores for each ePCK subscale for GIEE and non-GIEE teacher groups

\begin{tabular}{|c|c|c|c|c|c|}
\hline \multirow[b]{2}{*}{ Scales } & \multicolumn{3}{|c|}{ Mean \pm STD } & \multirow[b]{2}{*}{$\mathbf{T}$} & \multirow[b]{2}{*}{$\mathrm{Eta}^{2}$} \\
\hline & $\begin{array}{l}\text { GIEE graduate } \\
(N=44)\end{array}$ & $\begin{array}{c}\text { Not in GIEE group } \\
(N=86)\end{array}$ & $\begin{array}{c}\text { Total } \\
(N=130)\end{array}$ & & \\
\hline KSM & $15.8 \pm 2.3$ & $13.2 \pm 2.3$ & $14.1 \pm 2.6$ & 5.9 ** & 0.22 \\
\hline $\mathrm{KC}$ & $12.1 \pm 1.9$ & $10.0 \pm 1.9$ & $10.7 \pm 2.1$ & $6.1^{\star \star}$ & 0.28 \\
\hline $\mathrm{KL}$ & $15.2 \pm 2.1$ & $13.0 \pm 2.6$ & $13.7 \pm 2.6$ & $4.8^{\star \star}$ & 0.15 \\
\hline KIS & $14.3 \pm 2.8$ & $11.6 \pm 3.0$ & $12.5 \pm 3.1$ & $4.9^{\star \star}$ & 0.16 \\
\hline KEC & $20.4 \pm 2.9$ & $18.0 \pm 3.0$ & $18.7 \pm 3.2$ & $4.5^{\star \star}$ & 0.14 \\
\hline KEG & $24.8 \pm 4.0$ & $22.0 \pm 4.0$ & $22.9 \pm 4.2$ & $3.8^{\star \star}$ & 0.10 \\
\hline $\mathrm{KE}$ & $17.3 \pm 3.0$ & $15.2 \pm 3.2$ & $15.9 \pm 3.3$ & $3.8^{\star *}$ & 0.10 \\
\hline Total & $17.1 \pm 2.3$ & $14.7 \pm 2.3$ & - & $5.7^{\star \star}$ & 0.20 \\
\hline
\end{tabular}

To understand what impact the GIEE program might have on teachers' awareness about their PCK related to EE, we compared responses to the first two sections (demographics and subscales of ePCK) from teachers who completed the program (GIEE Group) to teachers who were not enrolled in the program (non-GIEE group). We used teacher demographics and experiences as independent variables to investigate how factors (e.g. gender, age, teaching career, PD in EE experiences, etc.) may influence on teachers' ePCK (dependent variables). For the ANOVA analysis, we compared scores in each scale depending on the variables in each group. A standardized

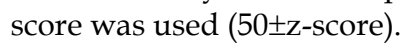

In addition, teachers in the GIEE group were asked to respond to ten additional self-evaluation (items \#52-61) questions and two open-ended questions (items \#62-63) to elicit these teachers' general comments about how the GIEE program impacted their awareness about ePCK and to provide suggestions about how the GIEE program could be improved to better support teachers' professionalism for teaching environmental education. The ten items were analyzed and teachers' percent responses to each subscale of the ePCK section were examined. Teachers in the non-GIEE group did not respond to items in this section. The two open-ended response questions were categorized as either positive or negative comments and excerpts were used to provide context for findings from teachers' self-evaluation about how their GIEE experiences impacted on their awareness of ePCK.

\section{FINDINGS AND DISCUSSION}

In the findings section, we first share overall findings regarding elementary school teachers' ePCK. Then we disaggregate the data to provide a more nuanced examination of the differences in ePCK perceptions between the teachers in each group. We then use the differences between each to investigate the potential impact of participation in the GIEE program on teachers' ePCK development. Next, we explore which variables may influence on elementary teachers' ePCK by examining factors (such as, number of years teaching, PD experiences, etc.) to examine the impact these variables have on responses in each teacher group. It is our assumption that any variables showing significant difference in ePCK sub-scales for teachers in the GIEE group, but not in the non-GIEE group, could be attributed to teachers' participation in the GIEE program. As such, we can potentially attribute gains in GIEE teachers' ePCK to their participation in the program. Finally, we examine teachers' perceptions about the GIEE program and we share teachers' responses concerning ways to further improve the program.

\section{Intergroup Comparisons of Teachers' Perceptions about ePCK}

In this section, we analyzed each item in all seven subscales of ePCK and we specially selected items that could provide meaningful and significant explanations for the differences in ePCK between the GIEE and non-GIEE teacher groups. We found there were significant differences between the two groups and the results of our analysis are comparable to findings from other EE and PCK related studies. The demographic data suggested that the GIEE and non-GIEE groups share many similarities, including average age and gender, years of teaching experience, school location, and number of students in their class. However, the teachers differed with regards to participation in EE focused in-service teacher training programs. The percentage of non-GIEE group of teachers engaging in this type of professional development was quite low (10\%) compared to teachers in the GIEE group (63.6\%). The results imply that the teachers in the GIEE group have more experience with EE, so the effect of the GIEE program on their ePCK was also analyzed.

Table 7 shows teachers' overall awareness about their own ePCK for each group of teachers. The total mean score analysis for ePCK for the GIEE group was 17.1 \pm 2.3 , and the total mean score for the non-GIEE group was $14.7 \pm 2.5\left(\mathrm{t}=5.7, \mathrm{Eta}^{2}=0.20\right)$. Teachers perceived they were strongest in the ePCK subscale, Knowledge of Educational Goal (KEG, $22.9 \pm 4.2$ ) and they perceived they were weakest in the ePCK subscale, Knowledge of Curriculum (KC, 
10.7 \pm 2.1 ). When we compared teachers' ePCK for both groups, we found there were significant differences for all subscales of ePCK (see Table 7). This implies that teachers who completed the GIEE were likely to possess a more positive perception of their knowledge to teach EE topics in the classroom than non-GIEE teachers.

\section{Overall Trends from Item-by-Item Analysis}

When we calculated the effect size to understand the strength of our results, all the effect sizes, with the exception of two, were medium to large according to Jacob Cohen's criteria for effect size interpretation (1988). Especially, items \#19, \#23, and \#29 were found to exceed Cohen's convention for a large effect (Eta ${ }^{2}, \# 19=0.23$, $\# 23=0.26$, \#29=0.20, p<0.001). These items were all related to teachers' understanding of unique aspects of environmental education, including the interdisciplinary and multidisciplinary nature of EE, the value of crosscurricular approaches, and the importance of students' attitudes towards the environment. Therefore, we found the GIEE program had large effects on teachers' ePCK in several knowledge domain areas. However, we found no significant differences in the mean values for item \#43, "I can design a teaching/learning goal that is suitable to develop the students' sensitivity and thoughtfulness towards the environment (in the Knowledge of Educational Goals (KEG) subscale)" and item \#51, "I can use assessment results from environmental education programs as resources to assess comprehensive development of a student at the end of a semester (in the Knowledge of Evaluation (KE) subscale)" (see Table 7).

This finding suggests that the GIEE program could be modified to better address teachers' needs in setting learning goals and in developing assessments that can effectively assess both students' content understanding and students' attitudes, such as environmental sensitivity. Research by Chu and her colleagues (2007) emphasized the importance of having teachers be able to promote environmental sensitivity in elementary school EE programs because improvements in student attitudes were positively correlated with an increase in students proenvironmental behaviors. Cho and Choi (2009) also empathized the need for developing Korean teachers' capacity for developing assessments suitable for students' abilities and characteristics should be improved and that teachers' knowledge of evaluation was a critical attribute for improving environmental education because this domain is related to the quality of instruction.

\section{Detailed Item-by-Item Analysis}

In this section, we provide more detailed findings for each of the seven knowledge domains. As we reported above, most items showed significant differences between groups (see Table 8) ${ }^{2}$.

\footnotetext{
${ }^{2}$ In this paper, we share item responses with the most significant differences. For permissible access to a full copy of the questionnaire, please contact the corresponding author at address provided in author's information section of this paper.
} 
Table 8. Summary of t test for selected items in each ePCK subscale $(N=130)$

\begin{tabular}{|c|c|c|c|c|c|}
\hline \multirow[b]{2}{*}{$\begin{array}{l}\text { Sub- } \\
\text { scales }\end{array}$} & \multirow[b]{2}{*}{ Item Statement } & \multicolumn{2}{|c|}{ Mean \pm STD } & \multirow[b]{2}{*}{$\mathbf{T}$} & \multirow[b]{2}{*}{$\mathrm{Eta}^{2}$} \\
\hline & & $\begin{array}{c}\text { GIEE } \\
\text { Graduate }\end{array}$ & $\begin{array}{c}\text { Not in } \\
\text { GIEE }\end{array}$ & & \\
\hline \multirow[t]{2}{*}{ KSM } & $\begin{array}{l}\text { \#16. I understand that current environmental issues and contents of } \\
\text { environmental education should be associated with each other. }\end{array}$ & $3.45 \pm 0.55$ & $3.02 \pm 0.67$ & $3.69^{* *}$ & 0.10 \\
\hline & \#17. I understand how environment, society and economy are related. & $3.27 \pm 0.59$ & $2.88 \pm 0.54$ & $3.68^{* *}$ & 0.10 \\
\hline \multirow{2}{*}{ KC } & $\begin{array}{l}\text { \#18. I understand the standard of environmental education in elementary school } \\
\text { as proposed by the government. }\end{array}$ & $2.39 \pm 0.81$ & $1.94 \pm 0.62$ & $3.18^{*}$ & 0.07 \\
\hline & $\begin{array}{l}\text { \#19. I understand that environmental education in elementary school is practiced } \\
\text { according to interdisciplinary approach or multidisciplinary approach. }\end{array}$ & $3.39 \pm 0.58$ & $2.65 \pm 0.67$ & $6.23^{* *}$ & 0.23 \\
\hline $\mathrm{KL}$ & $\begin{array}{l}\text { \#23. I understand students' interests and motivations for environmental } \\
\text { education. }\end{array}$ & $3.14 \pm 0.41$ & $2.57 \pm 0.64$ & $6.11^{* *}$ & 0.26 \\
\hline \multirow{3}{*}{ KIS } & $\begin{array}{l}\text { \#28. I understand teaching/learning methods that can help students to } \\
\text { understand basic ecological concepts. }\end{array}$ & $2.66 \pm 0.68$ & $2.22 \pm 0.64$ & $3.62^{\star *}$ & 0.09 \\
\hline & $\begin{array}{l}\text { \#29. I understand teaching/learning methods that can help students to increase } \\
\text { environmental sensitivity. }\end{array}$ & $2.93 \pm 0.66$ & $2.24 \pm 0.67$ & $5.58^{* *}$ & 0.20 \\
\hline & $\begin{array}{l}\text { \#30. I understand teaching/learning methods that can help students to improve } \\
\text { their inquiry ability. }\end{array}$ & $2.89 \pm 0.72$ & $2.48 \pm 0.72$ & $3.08^{*}$ & 0.07 \\
\hline KEC & $\begin{array}{l}\# 32 . \text { I understand the necessity of workshops or academic activities that are } \\
\text { related to environmental education. }\end{array}$ & $3.39 \pm 0.58$ & $2.87 \pm 0.59$ & $4.73^{* \star}$ & 0.15 \\
\hline KEG & $\begin{array}{l}\text { \#43. I can design a teaching/learning goal that is suitable to develop the } \\
\text { students' sensitivity and thoughtfulness towards the environment. }\end{array}$ & $2.82 \pm 0.76$ & $2.62 \pm 0.71$ & 1.51 & 0.02 \\
\hline KE & $\begin{array}{l}\# 51 . \text { I can use assessment results from environmental education programs as } \\
\text { resources to assess comprehensive development of a student at the end of a } \\
\text { semester. }\end{array}$ & $2.50 \pm 0.93$ & $2.65 \pm 0.67$ & 0.96 & 0.01 \\
\hline
\end{tabular}

Knowledge of Subject Matter: Teachers in both groups responded that they know they need to connect current environmental issues to EE (\#16, Mean \pm STD, GIEE group=3.45 \pm 0.55 ; non-GIEE group=3.02 $\pm 0.67, t=3.69, p<0.001$ ) and teachers' perceptions about the concept Education for Sustainable Development (ESD), which critically considers the relationships among environment, society, and economy (UNESCO, 2005), was relatively low in the non-GIEE group (\#17, Mean $\pm S T D$, GIEE group=3.27 \pm 0.59 ; non-GIEE group=2.88 $\pm 0.54, t=3.68, p<0.001)$. The effect size between group differences is the same in both items above $\left(E_{t a}^{2}=0.10\right)$, meaning the GIEE program has had a big impact on teachers' perceptions of current environmental education issues, including the need to consider ESD content and connections within the context of environmental education at the primary grade level.

Knowledge of Curriculum: Concerning the Korean National Standards for EE in elementary school (item \#18), teachers in both groups showed low positive perceptions (Mean $\pm S T D$, GIEE group $=2.39 \pm 0.81$; non-GIEE group=1.94 $\left.\pm 0.62 ; \mathrm{t}=3.18, \mathrm{Eta}^{2}=0.07, \mathrm{p}<0.05\right)$. This suggests that teachers in both groups have limited education or professional development about the actual standards to be taught in EE courses. The interdisciplinary feature of EE (Stevenson, Wals, Dillon, \& Brody, 2013) was well perceived by the teachers in the GIEE group compared to the non-GIEE group (item \#19). This could be attributed to the structure of the GIEE program itself, which has been designed to promote interdisciplinary approaches in EE. In addition, the GIEE program emphasizes the need to integrate content from both the sciences and humanities in order to fully appreciate the interconnectivity of the environment and society. Previous literature studies (McComas \& Wang, 1998; Summers, Childs, \& Corney, 2007) indicated that teachers should have opportunities through professional development or teacher training programs to closely consider the learning standards in different content areas so they can more feasibly try to integrate content when developing curriculum units and lessons.

Knowledge of Learner: For this domain, GIEE group teachers had significantly higher perceptions of students' preconceptions about the environment, interests and motivations for learning EE content, and understanding about the challenges for developing students' pro-environmental behaviors than non-GIEE teachers (Mean \pm STD, GIEE group=3.14 \pm 0.41 ; non-GIEE group $=2.57 \pm 0.64, \mathrm{t}=6.11, \mathrm{Eta}^{2}=0.26$ ). That the Eta squared value shows $26 \%$ of teachers' ePCK can be explained by a difference in the domain, Knowledge of Learners, can be interpreted to understand that the GIEE program is having a large and positive impact on teachers' understandings about who their students are and how they can effectively engage students to want to learn about environmental issues. Previous studies (Chu et al., 2007; Chu, Shin, \& Lee, 2006) have emphasized the importance of understanding students' attitudes and motivations towards EE due to the high correlation between positive attitudes and motivations and students' proenvironmental behaviors. Most EE teacher education programs suggest ways teachers can work to improve 
students' attitudes and motivations for engaging in EE, but research has shown that the possibility for improving students' pro-environmental behaviors decreases as students getting older (Chu et al., 2006). Our findings suggest that this consideration has been effectively communicated to teachers in the GIEE program and because they tend to be elementary teachers, graduates from this program have the potential to positively impact Korean children's views about the importance of the environment.

Knowledge of Instructional Strategies: There were also significant differences between the groups in Knowledge of Instructional Strategies (KIS), however the mean scores for all items were under 3 (Mean \pm STD, GIEE group, 2.66 \pm 0.68 to $2.93 \pm 0.66$; non-GIEE group, $2.22 \pm 0.64$ to $2.48 \pm 0.72$ ). Especially item \#29 showed a large mean score difference and Eta squared value between the GIEE and non-GIEE groups. This item measured teachers' ePCK about teaching/learning methods for increasing students' environmental sensitivity. Hungerford and Volk (1990) asserted that environmental sensitivity is one of the most critical EE components to be included in EE programs for teachers and EE curriculums for students. Our data suggests that a positive learning outcome for teachers in the GIEE program is an increased understanding about the importance of environmental sensitivity for increasing the likelihood that students will practice responsible environmental behaviors.

Knowledge of Environmental Context: For this domain, all teachers in the GIEE group recognized the necessity of participating in workshops for improving their knowledge (item \#32), EE service teacher training programs (item \#34), and field research opportunities (item \#35). In addition, GIEE teachers recognized the value of using diverse materials (item \#36) and the need to make connections between social institutions and the environment (item \#37). Thus, graduates of the GIEE program showed a significantly different appreciation for this knowledge domain compared to teachers in the non-GIEE group. This suggests that the GIEE program is positively influencing teachers' ePCK related to KEC.

\section{Factors Affecting Teachers' ePCK}

In this section, we explore factors that influence on teachers' perceptions by examining the impact of different variables on teachers' $\mathrm{ePCK}$, including teaching experience, gender, and school environment for enacting EE curriculum (e.g. access to resources for EE activities or appropriate facilities for EE in school). A comparison of various factors among teacher groups (GIEE and non-GIEE) helped us to evaluate the impact of the GIEE program on teacher participants' ePCK.

We found that teaching experience was an important influencing factor across most knowledge domains of ePCK for teachers in the non-GIEE group. In addition, teachers' participation in professional development for EE and teachers' age were shown to have some influence on non-GIEE group of teachers' Knowledge of Curriculum (KC) and Knowledge of Educational Context (KEC), respectively. However variables, such as, gender and teaching environment were found to have little or no impact on teachers' ePCK. In the sections that follow, we provide more detail about each variable and factor and we discuss possible reasons why some factors may have greater impact on ePCK for each group of teachers.

\section{Years of teaching experience}

We found that the number of years a person has been teaching was a significant factor influencing on teachers' ePCK, but only if they were in the non-GIEE program. Table 9 shows that teachers' ePCK in the GIEE group was not significantly influenced by their teaching experience. Interestingly, we found that an increase in years of teaching experience among GIEE participants had no impact on their perceptions of ePCK. This can be interpreted to suggest that the GIEE program may be able to supplement the kind of knowledge non-GIEE teachers gained from years of teaching experience-which suggests that participation in the GIEE program could somehow fill the knowledge gap that can exist between beginning teachers and veteran teachers. This has important implications regarding the benefit of participation in programs, such as the GIEE, as a means to improve teaching for new and beginning teachers. 
Table 9. Result of ANOVA: Comparison between groups according to years of teaching experience on ePCK

\begin{tabular}{|c|c|c|c|c|c|c|c|c|}
\hline \multirow{2}{*}{\multicolumn{2}{|c|}{$\begin{array}{l}\text { Teaching } \\
\text { Years }\end{array}$}} & \multicolumn{7}{|c|}{ Mean \pm STD of each scale } \\
\hline & & KSM & KC & $\mathbf{K L}$ & KIS & KEC & KEG & KE \\
\hline \multirow{5}{*}{$\begin{array}{l}\text { GIEE Graduate } \\
\qquad(\mathrm{N}=44)\end{array}$} & $0-5(\mathrm{~N}=11)$ & $50.6 \pm 1.1$ & $50.5 \pm 0.5$ & $50.4 \pm 0.7$ & $50.4 \pm 0.9$ & $50.3 \pm 0.8$ & $50.1 \pm 0.7$ & $50.0 \pm 0.9$ \\
\hline & $\begin{array}{c}5-10 \\
(N=23)\end{array}$ & $50.6 \pm 0.8$ & $50.6 \pm 0.9$ & $50.6 \pm 0.8$ & $50.6 \pm 0.8$ & $50.5 \pm 0.9$ & $50.5 \pm 0.9$ & $50.6 \pm 0.9$ \\
\hline & $\begin{array}{c}10 \text { or more } \\
(\mathrm{N}=10)\end{array}$ & $50.8 \pm 0.9$ & $50.9 \pm 1.1$ & $50.7 \pm 0.9$ & $50.6 \pm 1.1$ & $50.8 \pm 1.0$ & $50.7 \pm 1.3$ & $50.5 \pm 0.9$ \\
\hline & $\mathrm{F}$ & 0.24 & 0.49 & 0.44 & 0.27 & 0.71 & 1.27 & 1.59 \\
\hline & $\mathrm{Eta}^{2}$ & 0.01 & 0.02 & 0.02 & 0.01 & 0.03 & 0.06 & 0.07 \\
\hline \multirow{5}{*}{$\begin{array}{l}\text { Not in GIEE } \\
\quad(\mathrm{N}=85)\end{array}$} & $0-5(\mathrm{~N}=21)$ & $49.6 \pm 1.0$ & $49.5 \pm 0.9$ & $49.4 \pm 1.1^{a}$ & $49.3 \pm 0.8^{a}$ & $49.1 \pm 1.0^{\mathrm{a}}$ & $49.3 \pm 1.1^{\mathrm{a}}$ & $49.3 \pm 0.9^{a}$ \\
\hline & $\begin{array}{c}5-10 \\
(N=43) \\
\end{array}$ & $49.5 \pm 0.8$ & $49.7 \pm 0.8$ & $49.7 \pm 0.7$ & $49.7 \pm 0.9$ & $50.0 \pm 0.7^{b}$ & $49.9 \pm 0.8$ & $49.9 \pm 0.9$ \\
\hline & $\begin{array}{c}10 \text { or more } \\
(\mathrm{N}=22)\end{array}$ & $50.0 \pm 0.8$ & $49.8 \pm 1.1$ & $50.1 \pm 0.9^{b}$ & $50.1 \pm 1.1^{b}$ & $49.8 \pm 1.1$ & $50.0 \pm 1.0^{b}$ & $50.0 \pm 1.0^{b}$ \\
\hline & $F$ & 2.56 & 0.84 & $3.34^{\star}$ & $3.73^{*}$ & $7.13^{*}$ & $4.40^{*}$ & $4.51^{*}$ \\
\hline & $\mathrm{Eta}^{2}$ & 0.06 & 0.02 & 0.08 & 0.08 & 0.15 & 0.10 & 0.10 \\
\hline
\end{tabular}

However, for non-GIEE teachers, the more years they taught, the greater their ePCK in all domains. This was especially true for the Knowledge of Educational Context (KEC) domain. In fact, length of teaching career could be used to explain $15 \%$ of variance among the groups (0-5 years, $49.1 \pm 1.0 ; 5-10$ years, $50.0 \pm 0.7 ; 10$ or more years, $49.8 \pm 1.1 ; \mathrm{F}=7.13 ; \mathrm{p}<0.05)$, meaning that when teachers have more classroom experience, they may have broader knowledge about the various social, cultural, and tangible resources that would be effective for teaching EE at the elementary level. A study by Kamtet et al. (2010) found similar results when exploring the impact of teaching career on teachers' breadth and depth of knowledge. In this study, Kamtet et al. (2010) found that teachers' teaching experience had a positive impact on teachers' knowledge of content in science. This finding has implications for the benefit for improved environmental education for elementary students when the responsibility for teaching EE classes is assigned to more veteran teachers rather than to beginning teachers. These findings also suggest that new teachers could potentially offset their lack of teaching experience with experience and knowledge gained in a professional development program, such as the GIEE, which could support them to be more effective at instructing environmental education courses for elementary students than peers without similar training.

\section{Participation in professional development for environmental education}

We found that teachers' experiences with teacher professional development programs focused on EE topics had a significant impact on all ePCK domains (see Table 10). However, when separating out the GIEE and non-GIEE groups, there was only a significant difference in Knowledge of Curriculum (KC) for the non-GIEE teacher group and the effect size was small $(>5 \%)$. This would suggest that teacher-training programs were only effective in supporting teachers to develop knowledge about EE curriculum and the benefit for teachers who engage in this kind of teacher training program is almost negligible. 
EURASIA J Math Sci and Tech Ed

Table 10. Comparison between groups according to teachers' EE professional development experiences on ePCK

\begin{tabular}{|c|c|c|c|c|c|c|c|c|}
\hline \multirow{2}{*}{\multicolumn{2}{|c|}{ Group }} & \multicolumn{7}{|c|}{ Mean \pm STD } \\
\hline & & KSM & KC & $\mathbf{K L}$ & KIS & KEC & KEG & KE \\
\hline \multirow{4}{*}{$\begin{array}{l}\text { GIEE Graduate } \\
\qquad(\mathrm{N}=43)\end{array}$} & $\begin{array}{c}\text { Yes } \\
(N=28)\end{array}$ & $50.7 \pm 0.8$ & $50.6 \pm 0.8$ & $50.4 \pm 0.7$ & $50.5 \pm 0.8$ & $50.4 \pm 0.9$ & $50.3 \pm 0.9$ & $50.4 \pm 0.8$ \\
\hline & $\begin{array}{c}\text { No } \\
(N=15)\end{array}$ & $50.6 \pm 1.1$ & $50.8 \pm 1.1$ & $50.8 \pm 1.0$ & $50.7 \pm 1.0$ & $50.7 \pm 0.9$ & $50.6 \pm 1.1$ & $50.7 \pm 0.9$ \\
\hline & $F$ & 0.71 & 0.51 & 0.20 & 0.48 & 0.18 & 0.37 & 0.27 \\
\hline & $\mathrm{Eta}^{2}$ & 0.00 & 0.01 & 0.04 & 0.01 & 0.04 & 0.02 & 0.03 \\
\hline \multirow{4}{*}{$\begin{array}{l}\text { Not in GIEE } \\
\quad(\mathrm{N}=85)\end{array}$} & $\begin{array}{c}\text { Yes } \\
(\mathrm{N}=9)\end{array}$ & $50.2 \pm 0.7$ & $50.3 \pm 0.6$ & $50.1 \pm 0.6$ & $50.2 \pm 0.7$ & $50.2 \pm 0.6$ & $50.0 \pm 0.5$ & $50.3 \pm 0.4$ \\
\hline & $\begin{array}{c}\text { No } \\
(N=76)\end{array}$ & $49.6 \pm 0.9$ & $49.6 \pm 0.9$ & $49.7 \pm 1.0$ & $49.6 \pm 0.9$ & $49.7 \pm 0.9$ & $49.7 \pm 1.0$ & $49.7 \pm 0.9$ \\
\hline & $\mathrm{F}$ & 3.88 & $5.12^{*}$ & 1.58 & 3.65 & 2.95 & 0.56 & 3.85 \\
\hline & $\mathrm{Eta}^{2}$ & 0.05 & 0.06 & 0.02 & 0.04 & 0.03 & 0.01 & 0.04 \\
\hline \multirow{4}{*}{$\begin{array}{c}\text { Total } \\
(\mathrm{N}=128)\end{array}$} & Yes $(\mathrm{N}=37)$ & $50.6 \pm 0.8$ & $50.5 \pm 0.7$ & $50.3 \pm 0.7$ & $50.4 \pm 0.8$ & $50.3 \pm 0.8$ & $50.3 \pm 0.8$ & $50.4 \pm 0.7$ \\
\hline & $\mathrm{No}(\mathrm{N}=91)$ & $49.8 \pm 1.0$ & $49.8 \pm 1.0$ & $49.8 \pm 1.1$ & $49.8 \pm 1.0$ & $49.8 \pm 1.0$ & $49.9 \pm 1.0$ & $49.9 \pm 1.0$ \\
\hline & $\mathrm{F}$ & $19.69 * *$ & $16.79 * *$ & $7.42^{*}$ & $11.29 *$ & $6.55^{*}$ & $4.01^{*}$ & $8.12^{*}$ \\
\hline & $\mathrm{Eta}^{2}$ & 0.14 & 0.12 & 0.06 & 0.08 & 0.05 & 0.03 & 0.06 \\
\hline
\end{tabular}

${ }^{*} p<0.05,{ }^{* *} p<0.001$

Therefore, we argue that participation in existing in-service teacher training programs does not provide sufficient content for affecting positive change in teachers' ePCK. Thus, there is a need to improve current in-service teacher training programs to include greater emphasis on expanding teachers' knowledge aimed at supporting them to understand the contents of EE and to teach using appropriate methods that take into consideration various components of a school's context, such as students' abilities, needs, and interests and the availability of necessary educational resources for teaching EE to elementary age students.

\section{Gender, age, and teaching environment of teacher}

In this study, we wanted to assess if there were differences in gender because in Korea, elementary teachers are generally female. Some environmental education research has shown gender differences exist in adolescent boy and girls with regards to their knowledge, attitudes, and behaviors about the environment (Hampel, Boldero, \& Holdsworth, 1996; Lee, Shin, Chu, \& Ko, 2004). We hypothesized such findings could be explained by the influence that elementary teachers have on students' opportunities to learn about EE. Using F test results from our examination of gender, age, and teaching environment (e.g., location of school, class size, and support for implementation of EE activities in school), we determined there was no significant impact on teachers' ePCK in either the GIEE or non-GIEE teacher group for these factors.

We found there was no difference in teachers' awareness of ePCK based on gender (see Table 11). Our finding is similar to earlier research by Son (2005) that explored the correlation between gender and Korean teachers' professional development needs. Son collected five hundred survey responses from teacher participants regarding their professional needs in various aspects of practice and he found there was no significant difference in between men and women in teaching/learning readiness, understanding students, instructional skills, using media, and classroom management. While it is a common stereotype in Korea that male teachers are more adept to use media and technology and have fewer problems with classroom management compared to female teachers, Son's study found there was no empirical evidence to support these notions. 
Lee et al. / Factors Influencing Elementary Teachers' ePCK

Table 11. Results of MANOVA: The influence of gender on ePCK

\begin{tabular}{|c|c|c|c|c|c|c|c|c|}
\hline \multirow{2}{*}{\multicolumn{2}{|c|}{ Group }} & \multicolumn{7}{|c|}{ Mean \pm STD } \\
\hline & & KSM & KC & KL & KIS & KEC & KEG & KE \\
\hline \multirow{4}{*}{ GIEE Graduate } & $\begin{array}{l}\text { Female } \\
(\mathrm{N}=33)\end{array}$ & $50.7 \pm 0.9$ & $50.6 \pm 0.8$ & $50.5 \pm 0.8$ & $50.6 \pm 0.8$ & $50.5 \pm 0.9$ & $50.4 \pm 1.0$ & $50.4 \pm 1.0$ \\
\hline & Male $(\mathrm{N}=11)$ & $50.5 \pm 1.0$ & $50.8 \pm 1.0$ & $50.6 \pm 1.0$ & $50.5 \pm 1.0$ & $50.5 \pm 0.9$ & $50.4 \pm 0.9$ & $50.5 \pm 0.7$ \\
\hline & $\mathrm{F}$ & 0.23 & 0.27 & 0.04 & 0.05 & 0.03 & 0.00 & 0.18 \\
\hline & $\mathrm{Eta}^{2}$ & 0.005 & 0.006 & 0.001 & 0.001 & 0.001 & 0.000 & 0.004 \\
\hline \multirow{4}{*}{ Not in GIEE } & $\begin{array}{l}\text { Female } \\
(\mathrm{N}=58)\end{array}$ & $49.7 \pm 0.9$ & $50.0 \pm 0.9$ & $49.7 \pm 1.0$ & $49.8 \pm 0.8$ & $49.6 \pm 0.9$ & $49.7 \pm 1.0$ & $49.7 \pm 1.0$ \\
\hline & Male $(\mathrm{N}=28)$ & $49.6 \pm 0.9$ & $50.0 \pm 0.9$ & $49.7 \pm 1.0$ & $49.7 \pm 1.1$ & $50.0 \pm 1.0$ & $49.9 \pm 0.9$ & $49.9 \pm 1.0$ \\
\hline & $\mathrm{F}$ & 0.15 & 0.03 & 0.01 & 0.48 & $4.66^{\star}$ & 0.81 & 0.41 \\
\hline & $\mathrm{Eta}^{2}$ & 0.002 & 0.000 & 0.000 & 0.006 & 0.053 & 0.010 & 0.005 \\
\hline
\end{tabular}

*:p<0.05

Table 12. Results of ANOVA: The influence of teachers' age on ePCK

\begin{tabular}{|c|c|c|c|c|c|c|c|c|}
\hline \multirow{2}{*}{ Age } & & \multicolumn{7}{|c|}{ Mean \pm STD } \\
\hline & & KSM & KC & $\mathbf{K L}$ & KIS & KEC & KEG & KE \\
\hline \multirow{5}{*}{$\begin{array}{l}\text { GIEE Graduate } \\
\qquad(\mathrm{N}=44)\end{array}$} & $\begin{array}{c}21-30 \\
(\mathrm{~N}=16)\end{array}$ & $50.4 \pm 1.0$ & $50.4 \pm 0.9$ & $50.4 \pm 0.8$ & $50.3 \pm 1.0$ & $50.5 \pm 0.9$ & $50.2 \pm 0.8$ & $50.0 \pm 1.0$ \\
\hline & $\begin{array}{c}31-40 \\
(\mathrm{~N}=26) \\
\end{array}$ & $50.8 \pm 0.8$ & $50.8 \pm 0.8$ & $50.7 \pm 0.8$ & $50.7 \pm 0.8$ & $50.6 \pm 0.9$ & $50.6 \pm 1.0$ & $50.7 \pm 0.9$ \\
\hline & $\begin{array}{l}41-60 \\
(\mathrm{~N}=2)\end{array}$ & $50.2 \pm 0.3$ & $49.9 \pm 1.0$ & $50.1 \pm 0.5$ & $50.8 \pm 0.0$ & $50.4 \pm 0.9$ & $50.4 \pm 0.2$ & $50.6 \pm 0.0$ \\
\hline & $\mathrm{F}$ & 1.68 & 1.05 & 0.78 & 1.29 & 0.07 & 1.25 & 3.00 \\
\hline & $\mathrm{Eta}^{2}$ & 0.08 & 0.05 & 0.04 & 0.06 & 0.00 & 0.06 & 0.13 \\
\hline \multirow{5}{*}{$\begin{array}{l}\text { Not in GIEE } \\
\quad(\mathrm{N}=86)\end{array}$} & $\begin{array}{c}21-30 \\
(\mathrm{~N}=22) \\
\end{array}$ & $49.5 \pm 1.1$ & $49.5 \pm 1.0$ & $49.5 \pm 1.2$ & $49.5 \pm 0.9$ & $49.4 \pm 1.1^{a}$ & $49.5 \pm 1.0$ & $49.4 \pm 1.1$ \\
\hline & $\begin{array}{c}31-40 \\
(\mathrm{~N}=48)\end{array}$ & $49.7 \pm 0.8$ & $49.7 \pm 0.9$ & $49.7 \pm 0.8$ & $49.8 \pm 0.9$ & $49.8 \pm 0.8$ & $49.9 \pm 0.9$ & $49.9 \pm 0.8$ \\
\hline & $\begin{array}{c}41-60 \\
(\mathrm{~N}=16)\end{array}$ & $50.0 \pm 0.7$ & $49.7 \pm 0.8$ & $50.1 \pm 1.0$ & $49.8 \pm 1.2$ & $50.2 \pm 0.8^{b}$ & $49.9 \pm 1.0$ & $50.1 \pm 1.1$ \\
\hline & $\mathrm{F}$ & 0.94 & 0.77 & 1.47 & 0.59 & $3.65^{\star}$ & 0.88 & 2.96 \\
\hline & $\mathrm{Eta}^{2}$ & 0.02 & 0.02 & 0.03 & 0.01 & 0.08 & 0.02 & 0.07 \\
\hline \multirow{5}{*}{$\begin{array}{c}\text { Total } \\
(\mathrm{N}=130)\end{array}$} & $\begin{array}{c}21-30 \\
(\mathrm{~N}=38)\end{array}$ & $49.9 \pm 1.2$ & $49.9 \pm 1.1$ & $49.9 \pm 1.2$ & $49.8 \pm 1.0$ & $49.8 \pm 1.2$ & $49.8 \pm 1.0$ & $49.6 \pm 1.1^{\mathrm{a}}$ \\
\hline & $\begin{array}{c}31-40 \\
(\mathrm{~N}=74)\end{array}$ & $50.1 \pm 1.0$ & $50.1 \pm 1.0$ & $50.0 \pm 0.9$ & $50.1 \pm 1.0$ & $50.0 \pm 1.0$ & $50.1 \pm 1.0$ & $50.1 \pm 0.9$ \\
\hline & $\begin{array}{c}41-60 \\
(\mathrm{~N}=18)\end{array}$ & $49.9 \pm 0.6$ & $49.7 \pm 0.8$ & $50.1 \pm 0.9$ & $49.9 \pm 1.1$ & $50.2 \pm 0.8$ & $49.9 \pm 1.0$ & $50.2 \pm 1.0^{b}$ \\
\hline & $\mathrm{F}$ & 0.60 & 1.17 & 0.23 & 0.96 & 0.95 & 1.42 & $3.55^{\star}$ \\
\hline & $\mathrm{Eta}^{2}$ & 0.01 & 0.02 & 0.00 & 0.02 & 0.02 & 0.02 & 0.05 \\
\hline
\end{tabular}

${ }^{*}: p<0.05,{ }^{*}$ The different superscription represents a significant difference

However, when examining the relationship between teachers' age and ePCK, there was a significant difference for the Knowledge of Environmental Context (KEC) domain (see Table 12). This suggests that a teachers' KEC has the potential to influence on a teachers' awareness of which pedagogical strategies and social, cultural, and educational resources could be accessed and appropriated for teaching environmental education topics to elementary students. These include knowledge and understanding about what kinds of teaching practices may be effective for teaching specific content as well as an appreciation for understanding the value of connecting with social institutions and professional learning communities that can enhance students' environmental education learning experiences. When teachers have sufficiently developed KEC, they can appreciate the value of having students engage in environmental education learning experiences in a variety of settings and contexts and they recognize the benefits of collaborating with national, regional, and local EE programs and support services to expand students' opportunities for learning in authentic and meaningful ways (NAAEE, 2010). 
Table 13. Responses about impact of GIEE experiences on teachers' awareness of ePCK $(N=41)$

\begin{tabular}{|c|c|c|c|c|c|}
\hline Subscales & $\begin{array}{l}\text { Strongly } \\
\text { disagree }\end{array}$ & Disagree & Agree & $\begin{array}{l}\text { Strongly } \\
\text { agree }\end{array}$ & $\begin{array}{l}\text { Rating } \\
\text { average }\end{array}$ \\
\hline $\begin{array}{l}\text { Knowledge of Subject Matter } \\
\text { (2 items) }\end{array}$ & $\begin{array}{c}1 \\
(2.3)\end{array}$ & $\begin{array}{c}4 \\
(9.1)\end{array}$ & $\begin{array}{c}18 \\
(40.9)\end{array}$ & $\begin{array}{c}18 \\
(40.9)\end{array}$ & 3.29 \\
\hline $\begin{array}{l}\text { Knowledge of Curriculum } \\
\text { (1 item) }\end{array}$ & $\begin{array}{c}1 \\
(2.3)\end{array}$ & $\begin{array}{c}14 \\
(31.8)\end{array}$ & $\begin{array}{c}10 \\
(22.7)\end{array}$ & $\begin{array}{c}16 \\
(36.4)\end{array}$ & 3.00 \\
\hline $\begin{array}{l}\text { Knowledge of Learner } \\
(1 \text { item) }\end{array}$ & $\begin{array}{c}1 \\
(2.3)\end{array}$ & $\begin{array}{c}8 \\
(18.2)\end{array}$ & $\begin{array}{c}19 \\
(43.2)\end{array}$ & $\begin{array}{c}13 \\
(29.5)\end{array}$ & 3.07 \\
\hline $\begin{array}{l}\text { Knowledge of Instructional Strategies } \\
\text { (1 item) }\end{array}$ & $\begin{array}{c}1 \\
(2.3) \\
\end{array}$ & $\begin{array}{c}8 \\
(18.2) \\
\end{array}$ & $\begin{array}{c}17 \\
(38.6) \\
\end{array}$ & $\begin{array}{c}15 \\
(34.1) \\
\end{array}$ & 3.12 \\
\hline $\begin{array}{l}\text { Knowledge of Environmental Context } \\
\text { ( } 2 \text { items) }\end{array}$ & $\begin{array}{c}1 \\
(2.3)\end{array}$ & $\begin{array}{c}3 \\
(6.8) \\
\end{array}$ & $\begin{array}{c}20 \\
(45.5) \\
\end{array}$ & $\begin{array}{c}17 \\
(38.6) \\
\end{array}$ & 3.29 \\
\hline $\begin{array}{l}\text { Knowledge of Educational Goal } \\
\text { (1 item) }\end{array}$ & $\begin{array}{c}1 \\
(2.3)\end{array}$ & $\begin{array}{c}8 \\
(18.2) \\
\end{array}$ & $\begin{array}{c}15 \\
(34.1)\end{array}$ & $\begin{array}{c}17 \\
(38.6)\end{array}$ & 3.17 \\
\hline $\begin{array}{l}\text { Knowledge of Evaluation } \\
\text { ( } 2 \text { items) }\end{array}$ & $\begin{array}{c}5 \\
(11.4) \\
\end{array}$ & $\begin{array}{c}9 \\
(20.5) \\
\end{array}$ & $\begin{array}{c}14 \\
(31.8)\end{array}$ & $\begin{array}{c}13 \\
(29.5)\end{array}$ & 2.85 \\
\hline
\end{tabular}

Note: (\% in parenthesis)

It is interesting to note that teachers in the GIEE group, at all ages, showed consistent scores in KEC while teachers in non-GIEE group, aged 41-60, showed greater KEC understanding than teachers aged 21-30. ${ }^{3}$ While this finding has statistical limitation to be generalized due to the insufficient sample of teachers aged 41-60 in this study, this increase reflects similar findings related to the number of years teaching. This finding suggests that teachers in the GIEE group may have expanded their knowledge of KEC during the GIEE program, but teachers in the nonGIEE group were dependent on their teaching experiences for gaining this knowledge. The effective alignment of learning objectives, appropriate pedagogical practices and integration of available resources is more likely to occur once a teacher has accrued knowledge gained from years of practical teaching experience. Thus, the GIEE program may be helpful in providing KEC for teachers who could then use this knowledge to more effectively consider EE communities around their schools, region, or country. In addition, teachers who are aware of these resources may be better able to make use of these resources to help foster both cognitive and affective appreciation for environmental education issues, including improving students' understanding about the ways in which their individual actions and behaviors can impact on the environment.

\section{IMPACT OF GIEE PROGRAM PARTICIPATION ON TEACHERS' ePCK}

We asked teachers to evaluate what impact participation in the GIEE program has had on their ePCK by reflecting on six different ePCK knowledge domains, including Knowledge of Subject Matter, Knowledge of Curriculum, Knowledge of Learner, Knowledge of Instructional Strategies, Knowledge of Environmental Education Context, and Knowledge of Learning Goals. See Table 13 to examine teachers' percentage of positive responses about these teachers' perceptions about the impact of participation on the GIEE on their ePCK.

Teachers reported they were generally satisfied with their courses in terms of professional development for teaching EE as indicated by their positive responses (agree and strongly agree) on more than $50 \%$ of items in all categories. However, these teachers also indicated the GIEE program needed to be improved with regards to the Knowledge of Curriculum (KC) and Knowledge of Evaluation (KE) domains (Negative responses: $\mathrm{KC}=34.1 \%$, $\mathrm{KE}=31.9 \%$ ). Considering teachers' understanding of curriculum is crucial for effective implementation (Kwon, Chu, \& Park, 2006), the GIEE program should be designed with greater consideration about how to promote teachers' ability to participate in the curriculum development process and design their teaching. Especially, we believe that the GIEE curriculum should be designed to integrate concepts across different content disciplines, such as math or history by considering interdisciplinary features of EE. Also, the GIEE program should give an opportunity for teachers to re-construct EE curriculum by extracting subject matter from other areas to integrate into EE lessons. Finally, teachers should learn how to evaluate their teaching by examining changes in students' learning outcomes and by engaging in self-reflection. Research (Kimpston, 1985) has shown that the rhetoric-reality gap between planned curriculum and implemented curriculum can be reduced by expanding teachers' participation in

${ }^{3}$ Unlike in some other countries, such as the United States or Australia, in Korea, it is rare for a teacher to change their profession from one career to become a teacher later in life. As such, most people become teachers in their early-to-mid 20s and because public school teachers are in civil servant positions with a mandatory retirement age of 65 , the older a teacher is, the longer they have been working in this profession. Therefore, we can reasonably assume that the older a teacher is in our sample, the more years they have been teaching. Our findings reflect this trend (See Table 12). 
curriculum construction and by supporting teachers to engage curriculum evaluation and modification based on feedback from students and from experience (Kimpston, 1985).

These findings are also reflected in teachers' open ended-responses on the EST:ePCK, which prompted teachers to share their thoughts about the program (Question \# 62) and their suggestions for improving the program (Question \#63). Teachers commented that the program should be grounded in essential elements such as specific strategies to integrate subjects related to EE and that the program should offer more support to help teachers understand how to more effectively manage the curriculum including decision-making for content and methods to teach EE. One teacher remarked as follows:

\begin{abstract}
...the GIEE program needs to be revised so teachers can be given opportunities to design environmental lessons based on interdisciplinary or multidisciplinary approaches. Through this experience, teachers can reflect on their teaching and improve it by sharing practical ideas among peers (Open-end responses, Teacher \#33, 12/26/15)
\end{abstract}

This response echoes other teachers' comments showing that teachers have a tendency to negatively evaluate the impact of the program on the development of their KC and KE, both of which were relatively low. This is problematic because the grades K-6 curriculum for environmental education in Korea calls for teachers' efforts to develop their lessons EE using specific teaching/learning strategies and plans for evaluation based on national guidelines for EE. For example, to teach biological diversity, teachers should integrate subjects related the learning topic such as science, ethics and social studies and they need to make decisions about which teaching/learning methods are most appropriate for teaching this content. This reflects the need for teachers to have a strong Knowledge of Curriculum (KC). To evaluate students' cognitive, affective, and behavioral changes, teachers should also have knowledge about how to effectively assess students' environmental literacy, which means teachers need a strong understanding about Knowledge of Evaluation (KE). Therefore, the GIEE program should be designed with greater consideration for how to promote and develop teachers' knowledge connected to practical instruction for both KC and KE.

\title{
SUMMARY OF FINDINGS
}

In this study, we found some significant differences in GIEE and non-GIEE teachers' perceptions about ePCK and we identified some factors (including age and teaching experience) that may contribute to these differences.

First, in all knowledge domains of ePCK, there were significant differences between the two groups $(\mathrm{p}<0.001)$. Specifically, the effect size between group differences was high in subscales of KSM and KC (Eta ${ }^{2}, \mathrm{KSM}=0.22$, $\mathrm{KC}=0.28$ ). Teachers in the GIEE group were familiar with some major concepts in EE such as current environmental issue including ESD (item \#17 in KSM, Mean $\pm S T D$; GIEE group=3.27 \pm 0.59 ; non-GIEE group=2.88 $\pm 0.54, t=3.68$, $\mathrm{p}<0.001$ ) and interdisciplinary features of EE (item \#19 in KC, Mean $\pm S T D$; GIEE group, 3.39 \pm 0.58 ; non-GIEE group, $2.65 \pm 0.67, \mathrm{t}=6.23, \mathrm{p}<0.001)$. The GIEE group teachers also had more positives perceptions of learners who participate in environment education classes (item \#23 in KL, Mean $\pm S T D$; GIEE group, 3.14 \pm 0.41 ; non-GIEE group, $2.57 \pm 0.64 ; \mathrm{t}=6.11 ; \mathrm{p}<0.001)$ and reported a higher frequency of applying teaching and learning methods designed to promote students' environmental sensitivity (item \#29 in KIS, Mean \pm STD; GIEE group, 3.27 \pm 0.59 ; non-GIEE group, $2.88 \pm 0.54 ; \mathrm{t}=3.68 ; \mathrm{p}<0.001)$.

These findings suggest that teachers in the GIEE program were better able to perceive the importance of engaging community members and resources in the teaching of EE. In addition, these teachers were more aware of how to effectively set teaching and learning goals and how to apply appropriate evaluation methods for designing environmental class. Interestingly, while there were significant differences between the two groups in all subscales, teachers' responses on two individual items in the KEG and KE subscales showed no significant differences. For item \#43 of KEG (Mean $\pm S T D ;$ GIEE group, 2.82 \pm 0.76 ; non-GIEE group, 2.62 $\pm 0.71 ; \mathrm{t}=1.51$ ) which asks about setting goals for students' EE sensitivity development and item \#51 of KE (Mean \pm STD; GIEE group, 2.50 \pm 0.93 ; non-GIEE group, 2.65 $\pm 0.67 ; \mathrm{t}=0.96$ ) which asks about teachers' ability for using assessment results in existing EE programs as guidelines for assessing students' development, there were no significant differences between the groups regarding KEG and KE. Thus, it is recommended that the GIEE program do more to promote teachers' knowledge about how to effectively set teaching/learning goals for enhancing students' environmental sensitivity and to be able to more effectively use assessment results to improve students' learning.

Second, it was revealed that some aspects of a teachers' background might impact on their perceptions of ePCK. The duration of teaching experience variable mainly influenced on KEC in the non-GIEE group (0-5 years, 49.1 \pm 1.0 ; 5 -10 years, $50.0 \pm 0.7 ; 10$ or more years, $49.8 \pm 1.1 ; \mathrm{F}=7.13 ; \mathrm{p}<0.05)$. However, because there was no significant difference of ePCK recognition in the GIEE group, our findings suggest that the GIEE program could be effective for supplementing knowledge gained from actual teaching experiences. Similarly, teachers' experiences in teacher training about EE topics were found to positively impact on ePCK domain; there was only a significant difference 
in $\mathrm{KC}$ for the non-GIEE group teachers. This could be interpreted to suggest that the GIEE program can affect teachers' ePCK positively contrary to existing in-service teacher training programs.

Third, teachers who have taken the GIEE program were generally satisfied with their learning experiences. Teachers in the GIEE group responded that the program has positively impacted on all knowledge subscales of ePCK. Especially, the program helped teachers to understand major subject matter content of EE and the importance of using educational resources such as academic activities, collaborating with colleagues and connecting with social environmental education institutions (evidenced by positive response \%, KSM=81.8, $\mathrm{KEC}=84.1$ ). However, GIEE teachers indicated that the program needed to be improved with regards to KC and KE (evidenced by negative response \%, KC=34.1, KE=31.9). These results were reflected in teachers' comments about the program when asked for suggestions to help improve their courses. Teachers noted that the program should be more focused on providing opportunities to develop practical knowledge about how to integrate subjects related to EE so they could more effectively design environmental education lessons that were better aligned to the content standards in the EE curriculum.

\section{CONCLUSIONS AND DISCUSSION}

In this study, we developed and validated the EST: ePCK questionnaire to evaluate the impact participation in a graduate-level research-based interdisciplinary environmental education program had on teachers' ePCK. Using responses to the EST: $e P C K$, we made comparisons between teachers who were enrolled in the GIEE program and teachers who were not. We found that teachers who participated in this program had more positive perceptions of ePCK than those who did not, indicating that the GIEE program had some influence on developing teachers' PCK about environmental education.

Second, when comparing elementary teachers' perceptions of ePCK between GIEE and non-GIEE group teachers, we found participation in the GIEE had positive influences on growth in Knowledge of Subject Matter (KSM) and Knowledge of Curriculum (KC). However, deeper analysis of GIEE teachers' perceptions about their experiences in the program showed low positive responses in Knowledge of Curriculum (KC) and Knowledge of Evaluation (KE) domains. In open-ended responses, GIEE teachers indicated they had difficulties designing and implementing EE lessons in their classrooms, even though they were aware of the national standards and curriculum contents. However, teachers require a deeper understanding of the curriculum if they are to set educational goals and be able to effectively embed appropriate assessments in their lessons (Choi et al., 2007). This suggests that the program could be strengthened in these areas to better support teachers' EE practices in schools. Regarding this issue, there is considerable research in teacher education that shows a disconnect between what teachers learn in university coursework about best practices and the practices they actually implement in the classroom (Lee, et al. 2001; Park et al. 1997). In the Korean context, a study by Son et al., (2005) also found considerable differences between teachers' self-evaluation of their professional knowledge about the use of effective instructional strategies and the actual practices teachers enacted in the classroom.

In our study, teachers pointed out that the program has a rhetoric-reality gap between academic study and the actual needs of teachers, suggesting that all teachers would benefit from additional support to improve specific strategies for integrating subjects related to EE and other areas, such as classroom management. This gap could be narrowed by expanding teachers' competence in planning and by providing more structured opportunities for reflecting on the goals and content in school-level curricula with colleagues, administrators, and even parents and families (Westbury, Hansén, Pertti Kansanen, \& Björkvist, 2005). The EST: ePCK can provide programs, such as the GIEE, with a useful tool for conducting program evaluation to identify which areas are adequately supported by current coursework and for helping program administrators determine which areas need to be targeted for improvement.

Third, in consideration of the factors that impact on the teachers' perception of ePCK, we found the years of teaching experience can influence on teachers' ePCK. This finding is similar to results from a study by Kamtet et al. (2010), which examined how teachers' experience and length of career impacts on teachers' breadth and depth of knowledge. However, it is notable that there was no significant difference of ePCK recognition by teachers in the GIEE group, even for those with increased teaching experiences. Although teaching career is not the most or only important factor to develop a teachers' PCK (Grossman, 1989; Zainal, Mustapha, \& Habib, 2009), teacher education programs such as the GIEE can help teachers who have less teaching experience to enhance their professional knowledge and their PCK. Interestingly, we also found that for teachers in the non-GIEE group, experience in teacher training programs related to EE only improved a teachers' ePCK in relation to Knowledge of Curriculum (KC). This finding is consistent with research by Choi (2000) who found that existing in-service teacher training programs may be insufficient as it may not contain all the content necessary to affect positive change in teachers' PCK. Therefore, constructing and assessing teacher education programs should be considered in terms of conceptualizing the outcomes of teacher education (Cochran-Smith, 2001) and using comprehensive measures to know the effectiveness of each teacher education program (Darling-Hammond, 2006). In conclusion, 
multidisciplinary and research focused programs like the GIEE may be more effective in promoting the kinds of growth and development in a teachers' ePCK that could really benefit their teaching of EE in the classroom.

\section{IMPLICATIONS}

Previous research has shown that Korean teachers need professional development to improve their EE content knowledge, pedagogical knowledge, and general understanding about students as learners (Chu \& Son, 2014; Lee \& Choi, 2007ab?; North American Association for Environment Education [NAAEE], 2010; Son et al., 2005). Some efforts (Choi \& Lee, 2005; Choi, Lee, \& Youn, 2006; Lee \& Choi, 2007; Ministry of Environment [MOE], 2007) have been made to develop professional development programs to improve elementary teachers' competencies for teaching EE topics. Analysis of several such programs concluded (Lee \& Choi, 2007) that to be effective such programs needed focus on essential elements, such as developing instructional skills needed to teach $\mathrm{EE}$, introducing specific strategies to integrate EE with related subjects, and supporting teachers to improve classroom management skills. In response, the Korean MOE (2007) developed an EE curriculum for conducting elementary teacher in-service training programs. Because Korean teachers have greater than average participation in professional development and training than teachers from other OECD member countries (OECD, 2014), these programs could offer an effective strategy for improving these teachers' capacity for teaching EE. Unfortunately, not all professional development programs are equally effective in preparing teachers to learn how to develop lessons that comprehensively integrate EE concepts within or across different curriculum subjects or that teach $\mathrm{EE}$ as stand alone content.

Our study shows that teacher education programs, such as the GIEE, can positively influence teachers' perceptions about ePCK by enhancing teachers' professionalization related to various forms of knowledge about EE. However, in order for effective EE instructional practices to be implemented in teachers' classrooms, our findings suggest teacher education programs need to focus more attention on developing teachers' ability to apply the knowledge learned in the courses into real classroom settings. We suggest that in order for teacher education programs to provide effective curriculum for elementary teachers that improves EE teaching, programs need to offer courses designed using frameworks, such as ePCK, that help ensure various components of teachers' knowledge domains are addressed and enhanced. In addition, teacher education programs in EE need to offer experiences that are not only rich in theory, but also provide teachers with concrete, practical materials that are necessary for enhancing the teaching of EE topics in real classroom situations (Lee \& Choi, 2007). Through these endeavors, teachers can be encouraged to design their EE teaching comprehensively (Powers, 2004).

While this research was conducted in Korean schools, the issue of how to prepare elementary teachers (who are not EE content specialists), how to effectively integrate EE content across the curriculum is applicable to broader educational contexts. More research is needed about how to improve all areas of teachers' ePCK related to EE. Such research could have a direct impact on teachers' ability to effectively teach EE topics to students, both in Korean elementary schools and in primary schools in other countries that do not have a dedicated EE curriculum subject. Additionally, this research found that GIEE program teachers experienced an improved appreciation for interdisciplinary practices. In the future society, it will be essential for citizens to have a deeper understanding and appreciation for interdisciplinary content and research. Thus, teachers also need improved knowledge and capacity for teaching this content in ways that support students to be able to critically and logically consider ethical and effective decision-making about practices that impact on the environment and society. Programs that prepare teachers to be both knowledgeable and effective leaders in EE offers important implications for the education of all students about how to care for our local and global environments, both now and in the future. This research is a first step towards achieving this goal.

\section{ACKNOWLEDGEMENT}

This work was supported by the Ministry of Education of the Republic of Korea and the National Research Foundation of Korea (NRF-2016S1A3A2925401)

\section{REFERENCES}

Abdullaha, S. I. S. S., \& Halima, L. (2010). Development of instrument measuring the level of teachers' Pedagogical Content Knowledge (PCK) in environmental education. Social and Behavioral Sciences, 9, 174-178. https:/ / doi.org/10.1016/j.sbspro.2010.12.131

Abdullaha, S. I. S. S., \& Halima, L. (2012). Influence of teaching option and teaching experience on science teachers' Pedagogical Content Knowledge of environmental education. Journal of Korea Society of Science Education, 32(8), 1378-1389. https:/ / doi.org/10.14697/jkase.2012.32.8.1378 
Abell, S. (2008). Twenty years later: does pedagogical content knowledge remain a useful idea? International Journal of Science Education, 30, 1405-1416. https:/ / doi.org/10.1080/09500690802187041

Ahn, J., Choi, D., \& Cho, S. (2013). A study on the identity of environmental education as a subject. Environment Education, 26(3), 358-380.

Ardoin, N. M., Bowers, A. W., Roth, N. W., \& Holthuis, N. (2018). Environmental education and K-12 student outcomes: A review and analysis of research. The Journal of Environmental Education, 49(1), 1-17. https:/ / doi.org/10.1080/00958964.2017.1366155

Birdsall, S. (2015). Analyzing teachers' translation of sustainability using a PCK framework. Environmental Education Research, 21(5), 753-776. https:/ / doi.org/10.1080/13504622.2014.933776

Cho, S. \& Choi, D. (2009). A study on the Pedagogical Content Knowledge in pre-service environment teachers. Journal of Korean Society of Environmental Education, 22(3), 125-135.

Cho, S. (2010). The study on pedagogical content knowledge of environmental teachers: from environment teachers' perspective (Unpublished doctoral dissertation), Korea National University of Education, Chungbuk, Republic of Korea.

Choi, D., \& Lee, M. (2005). A study on developing and implementing in-service teacher training system to improve environmental literacy. Korean Journal of Teacher Education, 21(3), 255-276.

Choi, D., Jin, O., Lee, H., Son, Y., Lee, S., \& Cho, S. (2007). A Developmental Study on Teacher Professional Model and Standards of Assessing Students for Sustainable Environmental Education. Journal of Korean Society of Environmental Education, 20(1), 1-18.

Choi, D., Lee, M., \& Youn, S. (2006). Implementation and evaluation of in-service teacher training program for teaching-learning in environmental education. Journal of Korean Society of Environmental Education, 19(3), 183199.

Choi, S., Choi, K., Kim, Y., \& Kim, I. (2014). 환경교육론 (Pedagogy for environmental education). 서울: 교육과학사.

Choi, W. (2000). Training system of environment education teacher: Problem and prospect. Journal of Korean Society of Environmental Education, 13(1), 14-22.

Chu, H.-E., \& Son, Y.-A. (2014). The development of environmental education policy and programs in Korea: Promoting sustainable development in school environmental education. In J.C.K. Lee and R. Efird (Eds) Schooling for Sustainable Development across the Pacific: Schooling for Sustainable Development series (Vol 5.) (pp. 141-157). Springer: The Netherlands. https://doi.org/10.1007/978-94-017-8866-3_7

Chu, H.-E., \& Treagust, D. (2009). Korean students' environmental literacy and the environmental education program. In Neil Taylor, Michael Littledyke, Chris Eames, and Richard Coll (Eds), Environmental Education in Context, (pp. 299-306). Rotterdam: Sense Publishers.

Chu, H.-E., Lee, E. A., Ko, H. R., Shin, D. H., Lee, M. N., Min, B. M., et al. (2007). Korean year 3 children's environmental literacy: A prerequisite for a Korean environmental education curriculum. International Journal of Science Education, 29(2), 731-746. https:/ / doi.org/10.1080/09500690600823532

Chu, H-E., Shin, D.H., \& Lee, M. N. (2006). Korean students' environmental literacy and variables affecting environmental literacy. In S. Wooltorton \& D. Marinova (Eds), Sharing wisdom for our future environmental education in action (pp. 306-315). Australian Association for Environmental Education Conference Proceedings. Promaco Conventions, Canning Bridge, W.A, Australia.

Cochran-Smith, M. (2001). Constructing outcomes in teacher education: Policy, practice and pitfalls. Education Policy Analysis Archives, 9(11). https:/ / doi.org/10.14507/epaa.v9n11.2001

Cohen, J. (1988). Statistical power analysis for behavioral science (2nd ed.). Hillsdale, New Jersey: Lawrence Erlbaum Associates, Inc., Publishers.

Darling-Hammond, L. (2006). Assessing Teacher Education: The Usefulness of Multiple Measures for Assessing Program Outcomes. Journal of Teacher Education, 57(2), 120-138. https:/ / doi.org/10.1177/0022487105283796

Engleson, D. C., \& Yochers, D. H. (1994). A Guide to Curriculum Planning in Environmental Education. Wisconsin DPI. Retrieved on August 2017 from https:/ / files.eric.ed.gov/fulltext/ED380306.pdf

Faul, F., Erdfelder, E., Lang, A., \& Buchner, A. (2007). G*Power 3: A flexible statistical power analysis program for the social, behavioral, and biomedical sciences. Behavior Research Methods, 39(2). https:/ / doi.org/10.3758/BF03193146

GIEE. (2016). Interdisciplinary Program of Environmental Education at the College of Education. Retrieved on January 2016 from https:/ / enviroed.snu.ac.kr:8455/

Grossman, P. L. (1989). Learning to teach without teacher education. Teachers College Record, 91, 191-208. 
Hampel, B., Boldero, J., \& Holdsworth, R. (1996). Gender patterns in environmental consciousness among adolescents. Journal of Sociology, 32, 58-71. https:/ / doi.org/10.1177/144078339603200106

Hungerford, R. H., \& Volk, L. T. (1990). Changing learner behavior through environmental education. The Journal of Environmental Education, 21(3), 8-21.

Kamtet, W., Ngamman, J., Liewkongsthaporn, W., Pativisan, S., \& Dechsri, P. (2010). Assessing subject matter knowledge of science teachers. Retrieved from http:/ / www.iaea2010.com/fullpaper/415.pdf

Kimpston, R. D. (1985). Curriculum Fidelity and the Implementation Tasks Employed by Teachers: A Research Study. Journal of Curriculum Studies, 17(2), 185-195.

Kind, V. (2009) Pedagogical content knowledge in science education: perspectives and potential for progress. Studies in Science Education, 45(2), 169-204. https:/ / doi.org/10.1080/03057260903142285

Koh, J., Kang, W., Koh, J., Kwon, D., Kim, E., Pack, K., Park S., Park, Y., Seo, M., Lee, J., \& Jeong, H. (2007). 초등학교 교사론 (Elementary school teachers). Seoul: Republic of Korea.

Korea Institute for Curriculum and Evaluation. [KICE] (2007). 교육과정 개정에 따른 과학과 내용교수지식 (PCK) 연구 (The research on Pedagogical Content Knowledge (PCK) in science teaching). Seoul: Korea.

Korea Society for Environmental Education [KOSEE]. (2014). 국가 수준 환경교육 기준 개발 연구 (A study on the development of national environmental education standards). Ministry of Environment. Seoul: Republic of Korea.

Kwak, Y. (2011). 교사의 전문성 개발을 위한 교사 학습연구년제의 운영 방안 (Exploring teacher research sabbatical plan for professional development of teacher). Institute for Education Research in Korea National University of Education. Seoul: Korea. Retrieved from http:/ / cer.knue.ac.kr/bbs/outBoard.jsp?bodcode=cer_edu_forum\&fid=28\&oid=0\&depth=0\&selopt=\&ke $\mathrm{y}=\&$ page $=1 \&$ uid $=55 \&$ mode $=$ view

Kwon, H. \& Yun, S. (2010). A Qualitative Case Study on the Barriers Faced by Teachers in Choosing Environmental Education as the Creative Discretionary Activity in Elementary Schools. Journal of Korean Society of Environmental Education, 23(1), 50-63.

Kwon, N., Chu, K., \& Park, S. (2006). An Exploration of Determinant Factors for Teachers' Curriculum Implementation Level. Korean Society for Curriculum Studies, 24(3), 87-106.

Lee, E. A., Shin, D-H, Chu, H-E., \& Ko, H-R. (2004). The study of high school students' environmental literacy. Journal of Korean Earth Science Society, 25(3), 185-193.

Lee, S., \& Choi, D. (2007). A study on the components of teacher in-service training program to improve the professionalism in the elementary environmental education. Journal of Korean Society of Environmental Education, 20(2), 54-66.

Loughran, J. J., Mulhall, P., \& Berry, A. (2004). In search of pedagogical content knowledge in science: Developing ways of articulating and documenting professional practice. Journal of Research in Science Teaching, 41, 370391. https://doi.org/10.1002/tea.20007

Loughran, J. J., Mulhall, P., \& Berry, A. (2008). Exploring Pedagogical Content Knowledge in Science Teacher Education. International Journal of Science Education, 30(10), 1301-1320. https:/ / doi.org/10.1080/09500690802187009

Magnusson, S., Krajcik, J., \& Borko, I. (1999). Nature, sources and development of pedagogical content knowledge for science. In J. Gess-Newsome. \& N. G. Lederman. (Eds.), Examining pedagogical content knowledge (pp. 95132). Boston: Kluwer Academic Publisher. https:/ / doi.org/10.1007/0-306-47217-1_4

Marcinkowski, T. J., Volk, T. L., Hungerford, H. R., \& Kronholm, M. (1990). An environmental education approach to the training of middle level teachers: a prototype programme. In Environmental Education Series 30. UNESCO-UNEP International Environmental Education Programme. Retrieved on January 2016 from https:/ / files.eric.ed.gov/fulltext/ED337433.pdf

McComas, W. F., \& Wang, H. A. (1998). Blended science: The rewards and challenges of integrating the science disciplines for instruction. School Science and Mathematics, 98(6), 340-348. https://doi.org/10.1111/j.19498594.1998.tb17430.x

Messick, S. (1995). Validity of psychological assessment: Validation of inferences from persons' responses and performances as scientific inquiry into score meaning. American Psychologist, 50(9), 741-749.

Ministry of Environment [MOE]. (2007). 초등교사 환경교육연수 교육과정 개발 연구 (Developing curriculum for inservice elementary teacher training program in EE). Seoul: Republic of Korea. 
Ministry of Environment. (2010). 환경교육종합계획 '11-'15 (Environmental education master plan '11-'15). Seoul: Republic of Korea.

Nam, S. (1995). Environmental education in primary and secondary schools in Korea: current developments and future agendas, Environmental Education Research, 1(1), 109-122. https:/ / doi.org/10.1080/1350462950010109

Nam, S., Choi, D., Kim, K., \& Ha, G. (2001). 초등환경교과교육학 교재개발 연구 (A study on development of environmental education materials in elementary school). Research Center for Subject Matter Education in Korea National University of Education. Seoul: Republic of Korea.

North American Association for Environmental Education [NAAEE]. (2010). Guidelines for the Preparation and Professional Development of Environmental Educators. Retrieved from http:/ / resources.spaces3.com/5e156799-5cd9-406e-835d-748cce277ecf.pdf

Nunally, J. C., \& Bernstein, I. H. (1994). Psychometric theory (3rd Ed). New York: McGraw Hill.

OECD. (2014). TALIS 2013 Results: An International Perspective on Teaching and Learning, OECD Publishing. Retrieved from https:/ / doi.org/10.1787/9789264196261-en

Park, S. (2003a). Pedagogical content knowledge and predictor variables in science teaching of practicing elementary teachers. Journal of the Korean Association for Science Education, 23(6), 671-683.

Park, S. (2003b). The Development of PCK (Pedagogical Content Knowledge) Instrument in Science Teaching for Elementary School Teachers. The Journal of Korean Teacher Education, 20(1), 105-134.

Park, S. (2014). A study on the research trends of in-service teacher education in Korea: Implications and tasks. The Journal of Korean Teacher Education, 31(2), 227-254.

Powers, A. L. (2004). Teacher preparation for environmental education: Faculty perspectives on the infusion of environmental education into preservice methods courses. The Journal of Environmental Education, 35(3), 311.

Shulman, L. S. (1987). Knowledge and teaching: Foundations of the new reform. Harvard Education Review, 57(1), 122. https:// doi.org/10.17763/haer.57.1.j463w79r56455411

Shumba, O., \& Kampamba, R. (2012/2013). Mainstreaming ESD into science teacher education courses: A case for ESD pedagogical content knowledge and learning as connection. Southern African Journal of Environmental Education, 29, 151-166.

Son, Y., Kim, K., Min, B., \& Choi, D. (2005). Elementary teachers' professionalism for teaching environment subjects. Journal of Korean Society of Environmental Education, 24(2), 174-182.

Stevenson, R. B., Wals, A. E. J., Dillon, J., \& Brody, M. (2013). Introduction: An orientation to environmental education and the handbook. In R.B. Stevenson, A.E.J. Wals, J. Dillon, and M. Brody (Eds.), International Handbook of Research on Environmental Education (pp. 1-6). American Education Research Association.

Summers, M., Childs, A., \& Corney, G. (2005). Education for sustainable development in initial teacher training: issues for interdisciplinary collaboration. Environmental Education Research, 11(5), 623-647.

UNESCO. (2005). United Nations Decade of Education for Sustainable Development 2005-2014. Draft International $\begin{array}{lllll}\text { Implementation } & \text { Scheme. } & \text { January } & \text { Retrieved }\end{array}$ http:/ / unesdoc.unesco.org/images/0013/001399/139937e.pdf

UNESCO-UNEP. (1990). An environmental education approach to the training of middle level teachers: a prototype programme. In Environmental Education Series 30. UNESCO-UNEP International Environmental Education Programme.

Westbury, I., Hansén, S., Pertti Kansanen, P., \& Björkvist, O. (2005) Teacher Education for Research-based Practice in Expanded Roles: Finland's experience. Scandinavian Journal of Educational Research, 49(5), 475-485.

Zainal, T. Z. T., Mustapha, R., \& Habib, A. R. (2009). Pedagogical content knowledge for the title division among primary school mathematics teachers. Journal Pendidikan Malaysia, 34(1), 131-143. http:/ / dx.doi.org/10.17576/JPEN-2009-\%25x

Zhou, G. (2015). Environmental pedagogical content knowledge: A conceptual framework for teacher knowledge and development. In S. K. Stratton et al. (Eds.), Educating Science Teachers for Sustainability, ASTE Series in Science Education (pp. 185-203). Switzerland: Springer International Publishing. https:/ / doi.org/10.1007/978-3-319-16411-3_11

\section{http://www.ejmste.com}

